\title{
Remarks on the Proportions and Dimensions Used in the Design of the Medieval Church of Zsámbék
}

\author{
Krisztina Fehér ${ }^{1 *}$, Balázs Halmos ${ }^{1}$ \\ ${ }^{1}$ Department of History of Architecture and Monument Preservation, Faculty of Architecture, Budapest University of Technology \\ and Economics, H-1111 Budapest, Műegyetem rkp. 3., Hungary \\ * Corresponding author, e-mail: fkristin66@gmail.com
}

Received: 01 July 2019, Accepted: 31 October 2019, Published online: 28 November 2019

\begin{abstract}
Since the 19th century, the church of Zsámbék was continuously a focus of scholars' interest. The present paper intends to research the church ruins with a new aspect. Using an accurate terrestrial laser scan survey, the geometry of the plan is analysed in order to find proportions among the dimensions. The main goal of the study is to gather information about the design logic of the first masters of the 13th-century Premonstratensian abbey. In addition, our goal was to detect contributions to the 13th-century construction history of the church, that cannot be found in archives of graphic sources. The latest archaeological excavation achieved excellent results concerning several crucial historical points; however, the periodization of the church is still not entirely clarified. From the $19^{\text {th }}$ century, different scholars have proposed various hypotheses about this topic, without consensus.
\end{abstract}

Keywords

Zsámbék, medieval, geometry, proportion, 3D survey, laser scan

\section{Introduction}

The Premonstratensian Church of Zsámbék is one of the most precious monuments of Hungary. Besides its historical value, it is also an emblematic object of Hungarian monument preservation (Tombor, 1955, Guzsik, 1977; Marosi, 1996; Lővei, 1996; Fejérdy, 1998; Daragó, 2010; Dercsényi et al., 2007; Bardoly, 2010). Several scholars have researched the construction history of the church ruins since the 19th century (Möller, 1925; Lux, 1939; Guzsik, 1974a; 1974b; 1979; Bozóki, 2002; Dercsényi et al., 2007). According to the latest archaeological excavations of Ilona Valter, several details were clarified about the circumstances of the foundation and the history of the construction (Valter and Tamási, 1987; Valter, 1991a; 1991b; 1992; 1993; 1996; Dercsényi et al., 2007). While the early period of the land (e.g. the origins of the Aynard family, the period of the preceding church of one nave, possible foundation dates of the Premonstratensian abbey) has already been carefully assessed (Valter, 1991a; 1991b; 1992; 1993; 1996; Dercsényi et al., 2007), and the modern history of the monument is more or less clear, (Bozóki, 2002) the medieval period is still full of questions. Regarding the phases of the 13th-century construction, several hypotheses were published by Möller (1925),
Lux (1939) and Guzsik (1974; 1979). However, whether the whole Premonstratensian abbey was built in one or more phases is not yet clarified, and the versions of Möller, Lux and Guzsik are not entirely convincing.

The present paper intends to provide additional data regarding this open question.

As the archives and written sources about the history of the construction are rather limited, new scientific research methods can provide additional information. For instance, the calculation model of the seismic behavior of the church has recently revealed that the Komárom earthquake of 1763 did not destroy the whole construction (Belgya, 2014; Morais et al., 2017). Building archaeology and 'Bauforschung' (Fiorani, 1996; de Jonge and Balen; 2002; Schuller, 2002; Feilden, 2003; Adams, 2016; Diaz and Holzer, 2019) also provides direct and valuable data about the history. The research approach of the current paper is based on the terrestrial laser scanning of the church, representing an accurate 3D survey, and its geometrical analysis. During the research, numerical proportions of the 13th-century abbey were revealed on which the medieval conception of the plans could have been based. These results were compared with the current theory on 
medieval design methods of master masons, according to the international bibliography of the topic.

The use of 3D data recording is widely accepted and applied in heritage protection (Warden, 2009; Bryan, 2010; Watenpaugh, 2014; Xu et al., 2014; Quintero et al., 2017; Schmidt et al., 2019). For fast and accurate documentation, the application of various kinds of spatial object reconstruction methods, such as terrestrial laser scanning, structure for motion, 3D photogrammetry, videogrammetry and their combination with UAV technology (Bryan, 2010; Somogyi et al., 2017; Pan et al., 2019) is quite obvious. In recent years, the technology has developed rapidly, and its application has widened. The latest development of 3D data acquisition (Rodríguez-Gonzálvez et al., 2017; Masini et al., 2018) and improved possibilities of point cloud/mesh processing (e.g. cropping, compare) enable the efficient monitoring of monuments, and it is appropriate for detecting changes over time; for instance, the different phases of an archaeological excavation site (Macheridis, 2015) or changes (e. g. weathering, movement, sinking, of historical monuments (Fregonese et al., 2013; SánchezAparicio et al., 2016; Chen et al., 2018; Antón et al., 2019; Grilli and Remondino, 2019). The research method of the current paper also takes advantage of 3D surveying, which provided data for geometric analysis, and is also appropriate for any further analysis.

\section{Questions regarding the construction history}

The church has been a focus of interest since the beginning of institutional monument preservation in Hungary in the second half of the 19th century. Despite this, some important questions regarding the period covering the 13th-century construction are still open. The important archaeological excavations of Ilona Valter between 1986 and 1991, and the analysis of historical data about the early history of the village, the circumstances of the foundation of the monastery, the population of the church hill and the family who were the benefactors became clear (Valter, 1991a; 1991b; 1992; 1993; 1996; Dercsényi et al., 2007). According to Ilona Valter, the foundation of the Premonstratensian priory can be dated between 1210 and 1222, and certainly before the edition of Catalogus Ninivensis in 1234, which registered all the Premonstratensian monasteries of the region, including Zsámbék (Valter, 1991a; 1991b; 1996). Guzsik (1974a, 1974b) assumed that perhaps the church was never finished. The whole construction must have taken at least several decades of the 13th century. It is not sure, however, how the Mongol invasion of 1241-1242 influenced the construction, or if this period caused any changes in the design concept. The church clearly bears the characteristics of both Romanesque and Gothic architecture. While both the monastic order and the benefacting Aynard family were of French origins, and it is presumed by some scholars that initially French monks joined the new monastery of Zsámbék (Zsoldos, 2001), no close stylistic connection with French Romanesque or Gothic architecture is discussed in the literature. Still, in Subsection 2.1 on the calculation of units we will consider the possibility of using medieval French length units.

\subsection{Möller's periodization}

According to this, the first construction of the Premonstratensian abbey, several scholars proposed different hypotheses. István Möller (1925) distinguished three constructional periods with significant differences, worked out by French lodges before and after the Mongol invasion (Fig. 1). He supposed that, primarily, the whole late Romanesque basilica of three apses and two western towers was built during the first period. The nave was covered by a wooden ceiling, and the main apse was semi-circular (Fig. 1 (a)). In the second period, still before the Mongol invasion, the sacristy was built, and the ground floor spaces under and between the towers were vaulted (Fig. 1 (b)); the third period covered the restorations in early Gothic style after the Mongol destruction, while the wooden ceiling was destroyed by fire. The nave, the gallery and the first floor of the towers were vaulted. To support these vaults, buttresses were attached to the towers. The roof of the nave was rebuilt with a higher pitch, and the nave was rebuilt in a polygonal form. The great western portal and the rose-window were also built in this period (Fig. 1 (c)). In several areas, this periodization is far from realistic, but it must be emphasized that Möller lacked several pieces of information from archives, which were revealed decades after his examination of the site. His hypothesis is still interesting, as it was based on the direct observations of the ruins themselves (Möller, 1925), and since then, the ruins have faced further ruination as well as modifications (e.g. the loss of mural paintings, Fehér, 2008; Bóna, 2008; Bóna, 2009).

\subsection{Lux's periodization}

Opposed to Möller, his student, Géza Lux, believed that the 13th-century construction was not interrupted and the whole abbey was developed according to a single concept (Lux, 1939). He believed that the reason for the stylistic 

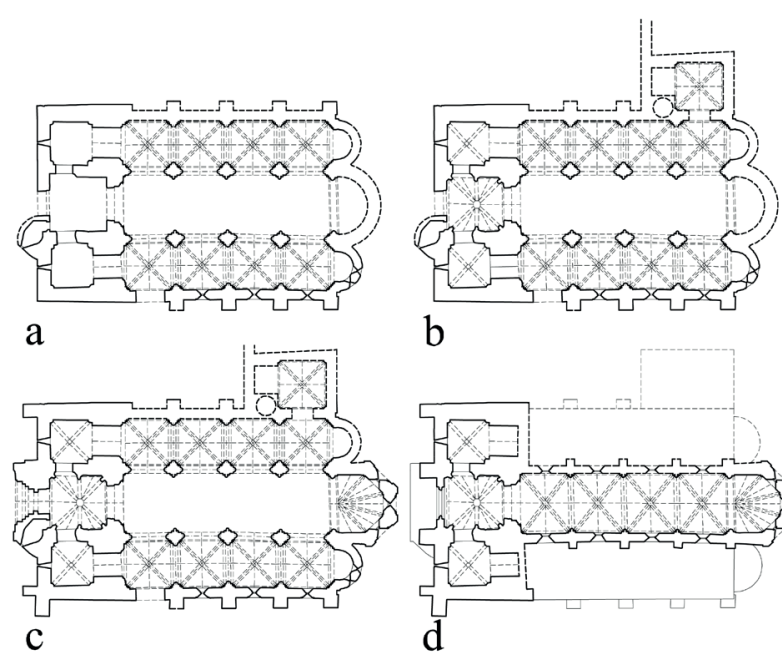

b

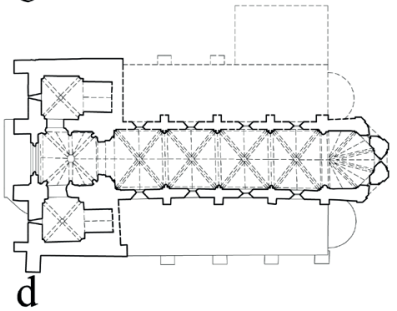

Fig. 1 István Möller's periodization regarding the 13th-century constructions (authors' drawing after Möller (1925))

heterogeneity (a mixture of Romanesque and Gothic elements) was the long-lasting construction that began with Romanesque characteristics and ended with new Gothic solutions. The present observations of the nave seem to strengthen Lux's hypothesis. However, based on the different types of wall textures (practically Fig. 1 (c)), the western part of two towers and the noble gallery were not built in one phase.

\subsection{Guzsik's periodization}

In 1974, Tamás Guzsik outlined a new periodization (Guzsik, 1974a; 1974b). According to his on-site observations, he claimed that the first church of a single nave that existed before the Premonstratensian basilica played a major role in the building's history (Fig. 2). He supposed that this church was still used during the Premonstratensians' construction that started with the building of the two western towers. (Fig. 2 (a)) In his hypothesis, the first plan of the basilica contained five bays and no chapels in the towers. (Fig. 2 (a)) In the next phase, the old church was connected to the new construction and two chapels were added to the towers. This resulted in the elongating of the towers; subsequently, in the new version of the plan, the nave contained only four bays (Fig. 2 (b)). After the Mongol invasion that destroyed the little church, the basilica was completed by a new group of masters from different lodges (Guzsik, 1974a; 1974b; 1979) (Fig. 2 (c)). He also revealed that some in situ stones were not properly carved (namely, the capitals above the Triumphal Arch). He deduced that perhaps the abbey was never entirely completed because the increasing building activity in Buda just absorbed the
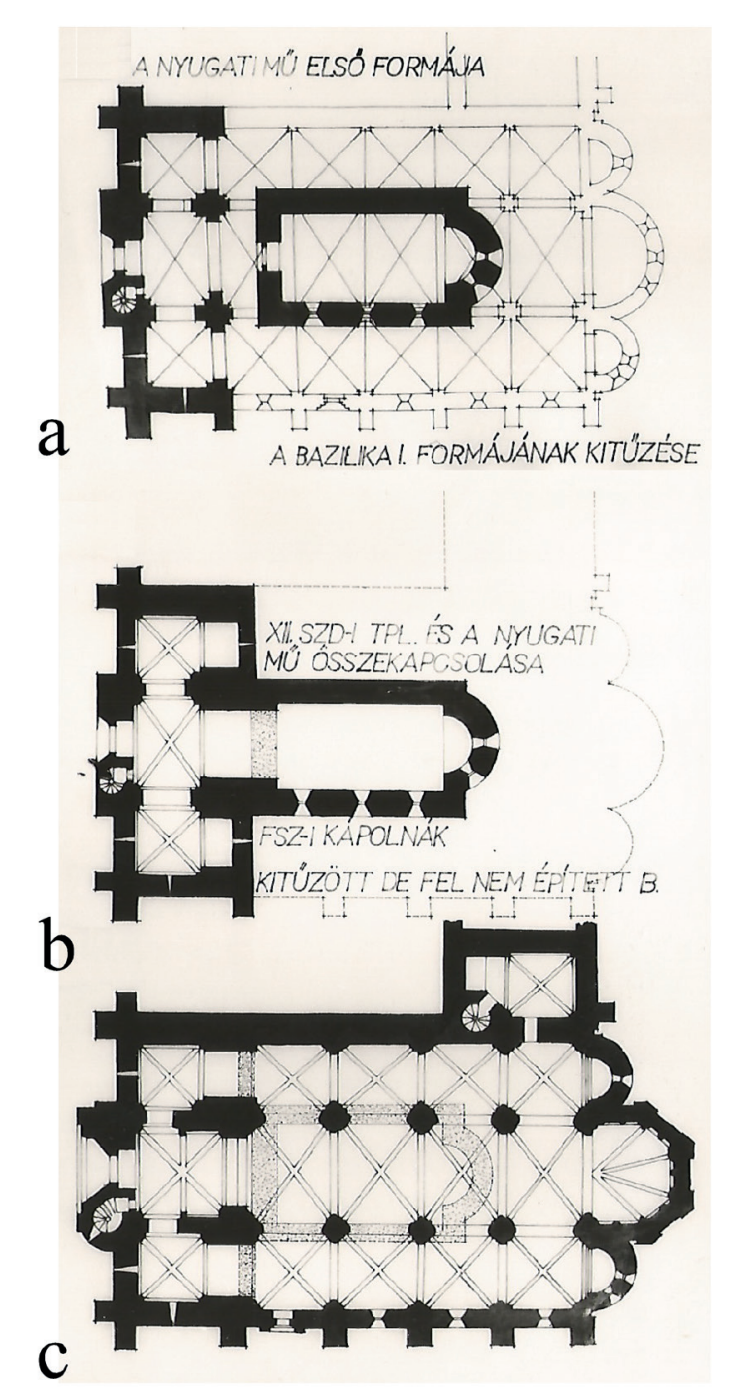

Fig. 2 Tamás Guzsik's periodization regarding the $13^{\text {th }}$-century constructions (figure after Guzsik (1974a; 1974b))

masters (Guzsik, 1974a; 1974b). His hypothesis is correct concerning the Western part which was undoubtedly built in several phases, and from the current geometrical analysis, its connection to the nave is rather incoherent. Guzsik assumed some ideas about the proportions and geometrical construction of the church plan. He found it interesting that Bogyay (1943) and Csemegi (1939) supposed a similar change of concept (from five to four bays of the nave) in the case of the Benedictine Abbey of Ják. In this case, Csemegi (1939) added that the plan with five bays seemed to be drawn by a quadratic system, while the plan of four bays was drawn by a triangular system. It is important to mention that Entz (1959) suggested that the same triangulation system was adequate for the plan of Zsámbék. The theoretical background of these design methods is described in Section 4.1. 
The further late Gothic constructions of the abbey of Zsámbék are well described by Ilona Valter, based on her excavations. After the disgrace of the Aynald dynasty, the domain became royal property. In the 15 th century, King Matthias Corvinus donated the monastery to the Order of Saint Paul the First Hermit. According to Valter (1991b), it is probable that until that time, several fires (one around 1453) destroyed some parts. The new monks had to restore the monastery and renovate it for their needs from 1484 (Zsoldos, 2001). The roof of the nave was raised the cloister and the southern porch of the church were modified with late Gothic characteristics. As these constructions only concerned minor parts without significantly modifying the church plan, the current geometrical analysis only covers the 13th-century structures.

\section{Research methods}

\subsection{Data capture}

The research approach of the study is based on the terrestrial laser scanning of the ruins and the geometric analysis. The results were compared with the information deduced from the onsite observations of the building (wall textures, carved details, appearance of different mortars). For the TLS data acquisition, a Leica BLK 360 instrument was used (Fig. 3). This device has been successfully utilised at several research and reconstruction projects at cultural heritage sites (Achille et al., 2018; de Lima et al., 2018; Chias and Abad, 2018; Diaz and Holzer, 2019; Luhmann et al., 2019). It can reach a nominal range accuracy of $4 \mathrm{~mm}$ at $10 \mathrm{~m}$ distance from the scanned surface (Leica Geosystems). This accuracy can be improved by the superposition of several scanned data and by reducing the scanning distance. The church was scanned from 30 positions (Fig. 4). The registration of the point clouds of the different positions was operated by shape matching method automatically on the spot by Autodesk Recap Pro software (Ogawa and Hori, 2019). The automatic alignment was supervised and if required, manually repeated later, during the data converting phase, also in Recap Pro (Fig. 5). The further point cloud processing was worked out manually using Autocad software (cropping). In order to collect accurate data for further geometric analysis, sections of the point cloud were needed. Autocad was also appropriate for vector polyline section generation (Fig. 6).

\subsection{Proportion analysis method}

For the geometrical analysis, a database of measured dimensions was created. As the church has been damaged

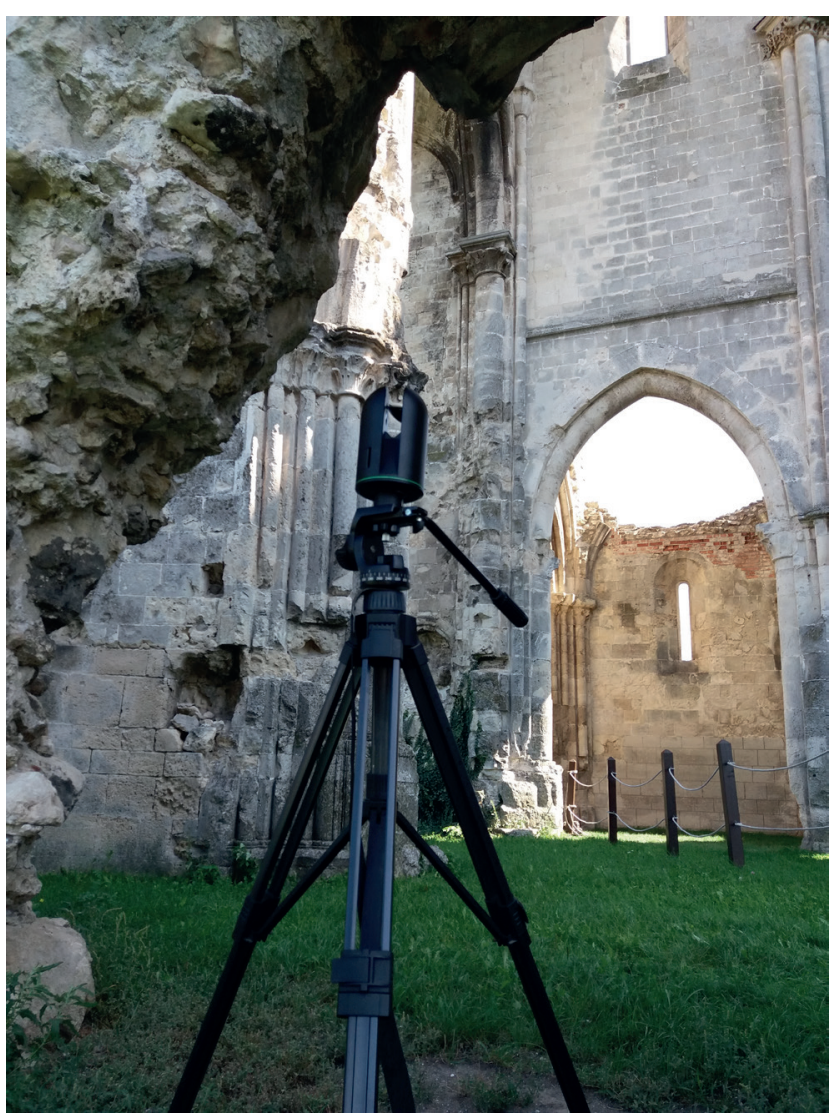

Fig. 3 Data acquisition by TLS (authors' photo)

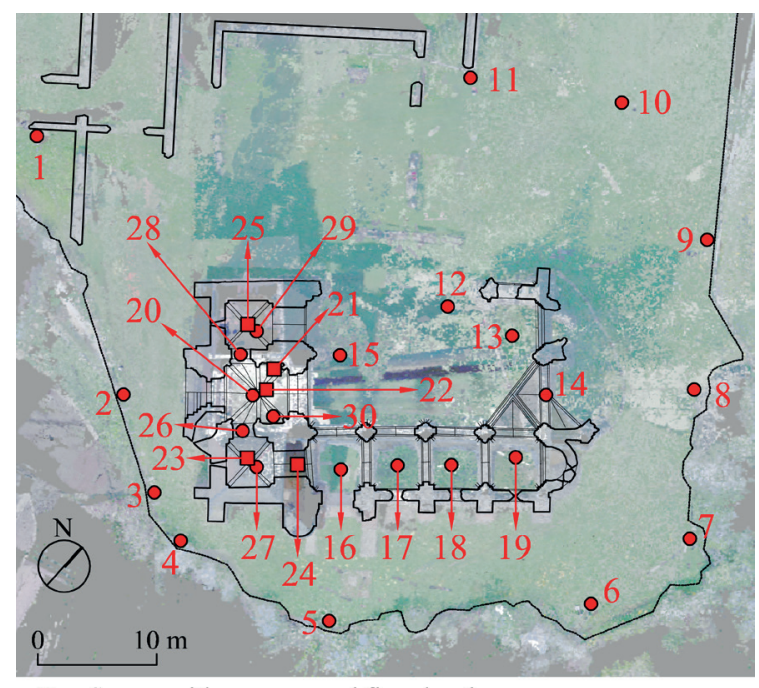

- Scan position on ground floor level

Scan position on gallery level

Fig. 4 TLS scan positions of the site work

with major (by an earthquake) and minor (by material abrasion of the stone, brick and mortar) deviations, it was crucial to define the places where the dimensions were recorded. The data was measured by both the $\mathrm{x}$ and $y$ scale of a defined coordinate system, with scales aligned to the two main directions of the walls (Fig. 6). Uniform 


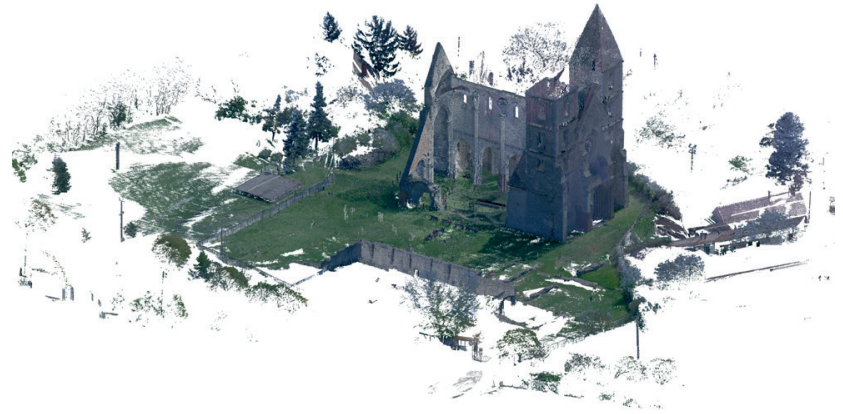

Fig. 5 TLS point cloud captured by Leica BLK 360

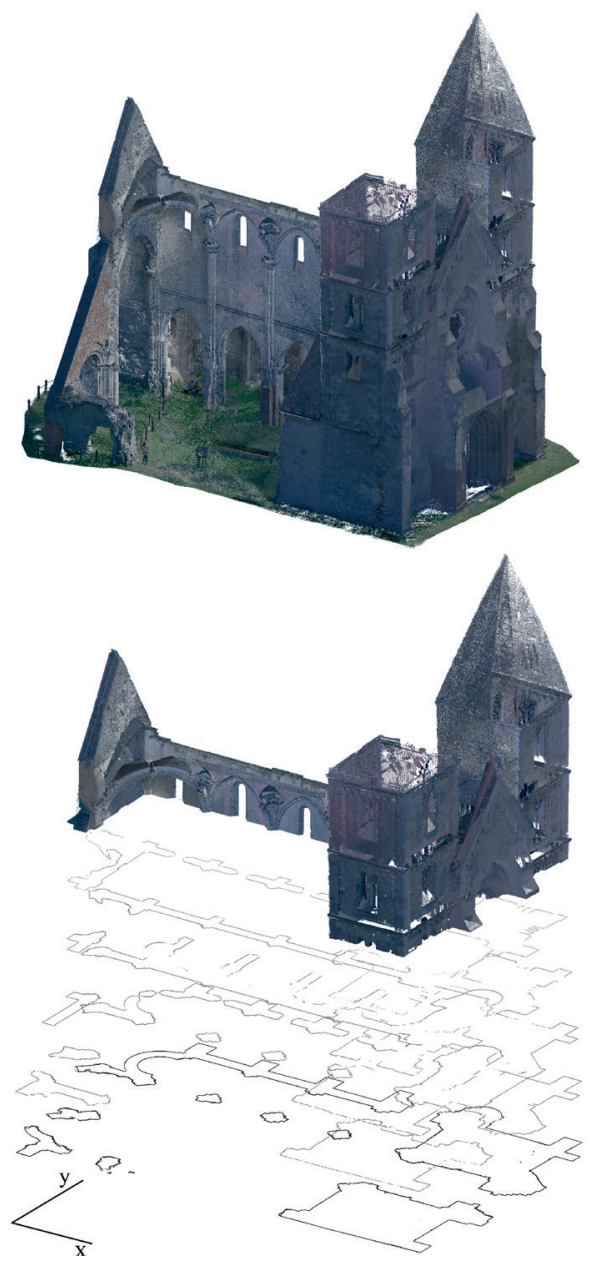

Fig. 6 Data processing of point cloud: a) crop, b) sections (authors' drawing)

dimensions were measured systematically in each bay: size of pillars, wall thickness, width and length of the spaces. In the case of width and length data, dimensions were measured both between axes and structures (Table 1 and see Fig. 7). As the wall surfaces of the ruins could have moved or deteriorated over the centuries, the original geometry of the building had to be carefully considered. In order to maximize the accuracy of the collected data, the dimensions were measured several times in different positions, with careful revision. Then, in order to deduce the quasi original ('ideal') dimensions of the church, the weighted arithmetic mean of each data sets were calculated. (Part I in Table 1) The current study is limited to the proportion examination of horizontal dimensions, due to the considerable uncertainty of vertical dimensions. The majority of vault keys are missing, and later movement of the construction could significantly modify heights, so original, vertical dimensions can be properly measured only in a very few positions.

\section{Theoretical background}

\subsection{Medieval design methods}

The question of medieval architectural design methods has a long tradition in Hungarian historiography. Since Imre Henszlmann's theory about proportioning methods (Henszlmann, 1860; Gergelyffy, 1958; Zádor, 1966; Levárdy, 1969), several research papers were published by various scholars (Fehér and Halmos, 2015). During this period, in accordance with the international historiography (Branner, 1957; 1963; Bucher, 1968; 1972; Conant, 1968; Shelby, 1971; Barnes, 1972; Murray, 1978; Bony, 1990), the most important medieval architectural sources were translated or initiated into the Hungarian bibliography (Villard de Honnecourt, Matthias Roriczer, Hans Schmuttermayer, Hans Hammer, Lorenz Lechler and other plans, archives, etc.) (Csemegi, 1936; Gerevich, 1971; Sódor, 1978a; 1978b; 1981; 1982; Sztanekné Apai, 1980; Entz, 1992; Hoppe, 1993; 1995). This theoretical knowledge was often turned into practical research, namely experiments were carried out to reconstruct the design methods of various Hungarian medieval monuments. In most of the cases, certain nets of geometrical figures were speculated under the drawings of buildings (Csemegi, 1939; 1953; Entz, 1959; Guzsik, 1974a; 1974b; Czagány, 1985; Fehér and Halmos, 2016). The two leading types of nets were based on the triangle and the square, i.e. 'triangulations' and 'quadrature'. In most of the cases, the main problem as to why these nets were highly doubtful was the inaccuracy of the drawing of the building, that served as the basis of the whole speculative geometric system. Besides this, the other question is whether triangulation and quadrature methods were really used by medieval master masons in such manner. There is some evidence proving that triangles, squares or pentagrams were used for architectural or figurative drawings, for instance, in the Portfolio of Villard de Honnecourt (Bechmann, 1991; Barnes, 2009). Also, the terms 'ad triangulum' and 'ad 
a

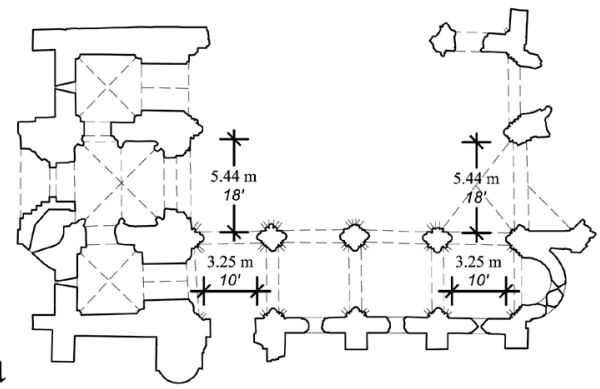

Width - length of nave bays (between pillars)
Actual ratio:
$1: 0.5974$
Speculated ratio
$9: 5$

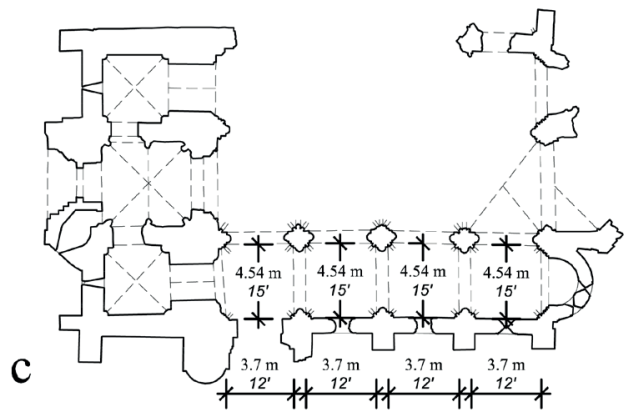

Width - length of S aisle bays (between walls and pillar cores)

Actual ratio:

$1: 0.8149$

Speculated ratio:

$5: 4$

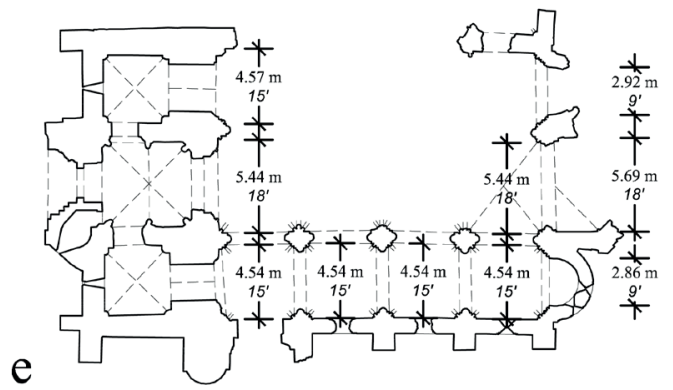

Actual ratio, Nave - $\mathrm{S}$ aisle:

$1: 0.8345$

Speculated ratio, Nave - $S$ aisle:

Actual ratio, Nave - $\mathrm{N}$ aisle:

$6: 5$

Speculated ratio, Nave - $N$ aisle:

$1: 0.84$

$6: 5$

Actual ratio, S aps.-Apse-N aps.: 0.502:1:0.513

Speculated ratio, S aps.-Apse-N aps.:

$1: 2: 1$ b

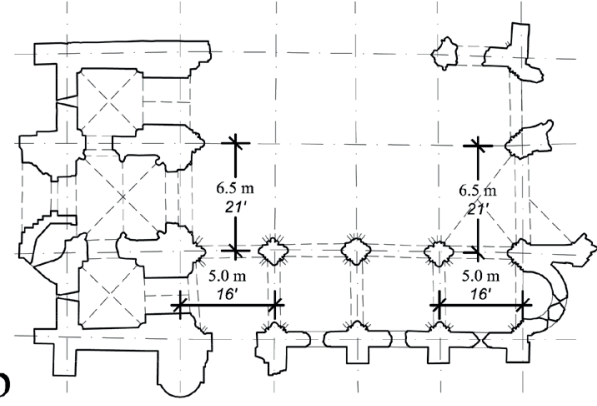

Width - length of nave bays (between axes)

Actual ratio:

$1: 0.7692$

Speculated ratio:

$21: 16(\approx 4: 3)$

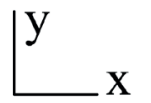

d

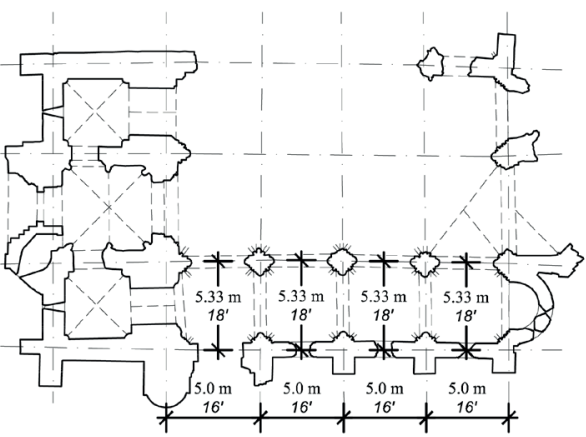

Width - length of S aisle bays (between axes)

$\begin{array}{lr}\text { Actual ratio: } & 1: 0.9380 \\ \text { Speculated ratio: } & 9: 8(\approx 11: 10)\end{array}$

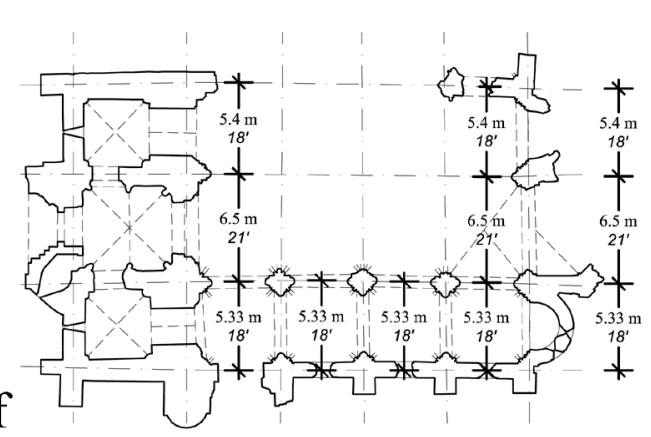

Actual ratio, Nave - $\mathrm{S}$ aisle (axes): $1: 0.82$

Speculated ratio, Nave - S aisle (axes): $\quad$ 7:6

Actual ratio, Nave - $\mathrm{N}$ aisle (axes): $1: 0.8307$

Speculated ratio, Nave $-N$ aisle (axes): $\quad$ 7:6

Fig. 7 Actual ratios calculated by measured data in SI and speculated ratios by the calculation of quasi-foot unit. Proportions of spaces, Part I in Table 2 (authors' drawing)

quadratum' appeared in the Annals of the building of Milan Cathedral in the context of serious constructional decisions (Ackerman, 1949). However, no direct medieval evidence can be found for using complex triangulation or quadratic net systems serving as a basis for the floor plan design. The idea originated from the 19th century when several speculative theories were developed concerning medieval design methods (Csemegi, 1953; Fehér and Halmos, 2015; 2016). Medieval sources indicate that triangle, square and also pentagon formats (Fehér et al., 2019) were used for plan and detail design, but the logic for these approaches varies widely (Shortell, 2002; Wu, 2002). Without the original plans, any reconstruction of the design cannot exceed hypothesis. The question of medieval design methods is 
Table 1 Database of measures. Part I: arithmetic mean of measured dimensions. Part II: converting dimensions to known historical units Integers $(+/-1 \mathrm{~mm})$ and halves are indicated in red. Part III: inverse foot unit calculation

\begin{tabular}{|c|c|c|c|c|c|c|c|c|c|c|c|c|c|c|}
\hline \multicolumn{3}{|l|}{$\begin{array}{c}\text { PART I } \\
\text { DIMENSIONS }\end{array}$} & \multicolumn{9}{|c|}{$\begin{array}{c}\text { PART II } \\
\text { CONVERTING TO KNOWN HISTORICAL UNITS }\end{array}$} & \multicolumn{2}{|c|}{$\begin{array}{c}\text { PART III } \\
\text { INVERSE UNIT } \\
\text { CALCULATION } \\
\end{array}$} & \multirow[b]{2}{*}{$\begin{array}{l}\text { NOTES ON DATA } \\
\text { AND RESULTS }\end{array}$} \\
\hline $\begin{array}{l}\text { Data type: description of } \\
\text { dimension }\end{array}$ & 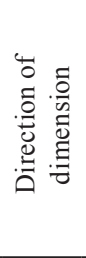 & 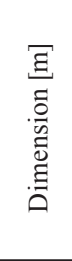 & 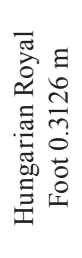 & 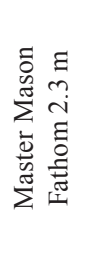 & 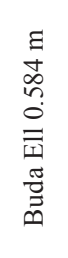 & 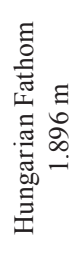 & 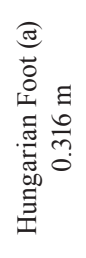 & 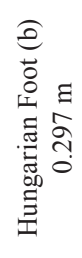 & 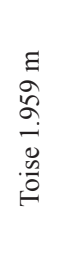 & 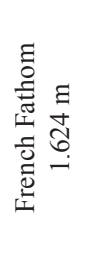 & 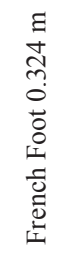 & 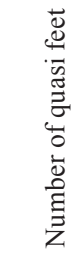 & 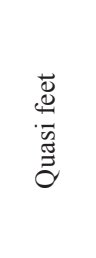 & \\
\hline $\begin{array}{l}\text { Nave: width (between } \\
\text { pillars) }\end{array}$ & $\mathrm{y}$ & 5.44 & 17.4 & 2.4 & 9.3 & 2.9 & 17.2 & 18.3 & 2.8 & 3.3 & 16.8 & 18 & 0.302 & $\begin{array}{l}\text { Clear measurement. } \\
\text { similar data in each bay }\end{array}$ \\
\hline $\begin{array}{l}\text { Nave: width (between } \\
\text { axes) }\end{array}$ & $\mathrm{y}$ & 6.5 & 20.8 & 2.8 & 11.1 & 3.4 & 20.6 & 21.8 & 3.3 & 4.0 & 20.0 & 21 & 0.309 & $\begin{array}{l}7 \mathrm{~cm} \text { difference } \\
\text { between measurements }\end{array}$ \\
\hline $\begin{array}{l}\text { Nave: spin of arcades } \\
\text { / length of a bay } \\
\text { (between pillars) }\end{array}$ & $x$ & 3.25 & 10.4 & 1.4 & 5.6 & 1.7 & 10.3 & 10.9 & 1.7 & 2.0 & 10.0 & 10 & 0.325 & $\begin{array}{l}30 \mathrm{~cm} \text { difference } \\
\text { between measurements }\end{array}$ \\
\hline $\begin{array}{l}\text { Nave: length of a bay } \\
\text { (gallery level) (between } \\
\text { wall-pillars) }\end{array}$ & $\mathrm{x}$ & 4.27 & 13.7 & 1.9 & 7.3 & 2.3 & 13.5 & 14.3 & 2.2 & 2.6 & 13.2 & 14 & 0.305 & $\begin{array}{l}\text { Data with } 20 \mathrm{~cm} \\
\text { standard deviation }\end{array}$ \\
\hline $\begin{array}{l}\text { Nave: spin of arcades } \\
\text { (between axes) and } \\
\text { spin length of wall in } \\
\text { one bay (gallery level) } \\
\text { (between axes) }\end{array}$ & $\mathrm{x}$ & 5.0 & 16.0 & 2.2 & 8.6 & 2.6 & 15.8 & 16.8 & 2.6 & 3.1 & 15.4 & 16 & 0.312 & $\begin{array}{l}\text { Clear measurement. } \\
\text { similar data in each bay }\end{array}$ \\
\hline $\begin{array}{l}\text { Southern aisle: width } \\
\text { (between pillars) }\end{array}$ & $\mathrm{y}$ & 3.39 & 10.8 & 1.5 & 5.8 & 1.8 & 10.7 & 11.4 & 1.7 & 2.1 & 10.5 & 10 & 0.339 & $\begin{array}{l}\text { Clear measurement. } \\
\text { similar data in each } \\
\text { bay, except bay no. } \\
4 \text { (rebuilt by János } \\
\text { Sedlmayr) }\end{array}$ \\
\hline $\begin{array}{l}\text { Southern aisle: width } \\
\text { (between walls and } \\
\text { pillar cores) }\end{array}$ & $\mathrm{y}$ & 4.54 & 14.5 & 1.9 & 7.7 & 2.4 & 14.4 & 15.3 & 2.3 & 2.8 & 14.0 & 15 & 0.302 & $\begin{array}{l}\text { Clear measurement. } \\
\text { similar data in each bay }\end{array}$ \\
\hline $\begin{array}{l}\text { Southern aisle: width } \\
\text { (between axes) }\end{array}$ & $\mathrm{y}$ & 5.33 & 17.1 & 2.3 & 9.1 & 2.8 & 16.9 & 17.9 & 2.7 & 3.3 & 16.4 & 18 & 0.296 & $\begin{array}{l}\text { Clear measurement. } \\
\text { similar data in each } \\
\text { bay, except bay no. } \\
4 \text { (rebuilt by János } \\
\text { Sedlmayr) }\end{array}$ \\
\hline $\begin{array}{l}\text { Southern aisle: length } \\
\text { of a bay (between wall- } \\
\text { pillars) }\end{array}$ & $\mathrm{x}$ & 3.69 & 11.8 & 1.6 & 6.3 & 1.9 & 11.7 & 12.4 & 1.9 & 2.3 & 11.4 & 12 & 0.307 & $\begin{array}{l}\text { Clear measurement. } \\
\text { similar data in each } \\
\text { bay, except bay no. } \\
4 \text { (rebuilt by János } \\
\text { Sedlmayr) }\end{array}$ \\
\hline $\begin{array}{l}\text { Southern aisle: length } \\
\text { of a bay (between wall- } \\
\text { pillar cores) }\end{array}$ & $\mathrm{x}$ & 3.70 & 11.8 & 1.6 & 6.3 & 1.9 & 11.7 & 12.5 & 1.9 & 2.3 & 11.4 & 12 & 0.309 & $\begin{array}{l}\text { Clear measurement. } \\
\text { similar data in each } \\
\text { bay, except bay no. } \\
4 \text { (rebuilt by János } \\
\text { Sedlmayr) }\end{array}$ \\
\hline $\begin{array}{l}\text { Southern aisle: length } \\
\text { of a bay (between axes) }\end{array}$ & $\mathrm{x}$ & 5.0 & 16.0 & 2.2 & 8.6 & 2.6 & 15.8 & 16.8 & 2.6 & 3.1 & 15.4 & 16 & 0.312 & $\begin{array}{l}\text { Clear measurement. } \\
\text { similar data in each bay }\end{array}$ \\
\hline $\begin{array}{l}\text { Northern aisle: width } \\
\text { (between wall-pillars) }\end{array}$ & $\mathrm{y}$ & 4.57 & 14.6 & 1.9 & 7.8 & 2.4 & 14.4 & 15.4 & 2.3 & 2.8 & 14.1 & 15 & 0.304 & $\begin{array}{l}\text { uncertain data, because } \\
\text { the wall of the sacristy } \\
\text { is oblique }\end{array}$ \\
\hline $\begin{array}{l}\text { Northern aisle: width } \\
\text { (between axes) }\end{array}$ & $\mathrm{y}$ & 5.4 & 17.3 & 2.3 & 9.2 & 2.8 & 17.1 & 18.1 & 2.8 & 3.3 & 16.7 & 18 & 0.300 & $\begin{array}{l}\text { Discrepancy of } \\
\text { measured data because } \\
\text { of new surfaces of } \\
\text { Sedlmayr's restoration }\end{array}$ \\
\hline
\end{tabular}




\begin{tabular}{|c|c|c|c|c|c|c|c|c|c|c|c|c|c|c|}
\hline $\begin{array}{l}\text { Apse: width (between } \\
\text { walls) }\end{array}$ & $\mathrm{y}$ & 5.69 & 18.2 & 2.5 & 9.7 & 3.0 & 18.0 & 19.1 & 2.9 & 3.5 & 17.6 & 18 & 0.316 & $\begin{array}{l}\text { Few places to measure } \\
\text { this data }\end{array}$ \\
\hline $\begin{array}{l}\text { Southern apsidiol: } \\
\text { width (between walls) }\end{array}$ & $\mathrm{y}$ & 2.86 & 9.1 & 1.2 & 4.9 & 1.5 & 9.0 & 9.6 & 1.5 & 1.8 & 8.8 & 9 & 0.318 & $\begin{array}{l}\text { Apse reconstructed } \\
\text { by Möller with high } \\
\text { accuracy }\end{array}$ \\
\hline $\begin{array}{l}\text { Southern apsidiol: inner } \\
\text { diameter }\end{array}$ & - & 2.85 & 9.1 & 1.2 & 4.9 & 1.5 & 9.0 & 9.6 & 1.5 & 1.8 & 8.8 & 9 & 0.317 & $\begin{array}{l}\text { Apse reconstructed } \\
\text { by Möller with high } \\
\text { accuracy }\end{array}$ \\
\hline $\begin{array}{l}\text { Northern apsidiol: } \\
\text { width (between walls) }\end{array}$ & $\mathrm{y}$ & 2.92 & 9.3 & 1.3 & 5.0 & 1.5 & 9.2 & 9.8 & 1.5 & 1.8 & 9.0 & 9 & 0.324 & $\begin{array}{l}6 \mathrm{~cm} \text { difference } \\
\text { between measurements } \\
\text { because of surface } \\
\text { decay }\end{array}$ \\
\hline $\begin{array}{l}\text { Northern apsidiol: inner } \\
\text { diameter }\end{array}$ & - & 2.84 & 9.1 & 1.2 & 4.9 & 1.5 & 9.0 & 9.5 & 1.4 & 1.7 & 8.8 & 9 & 0.316 & $\begin{array}{l}\text { Semi-circle with a } \\
\text { slight distortion }\end{array}$ \\
\hline $\begin{array}{l}\text { Nave: wall thickness } \\
\text { (gallery level) }\end{array}$ & $\mathrm{y}$ & 0.85 & 2.7 & 0.4 & 1.5 & 0.4 & 2.7 & 2.9 & 0.4 & 0.5 & 2.6 & 2.5 & 0.340 & $\begin{array}{l}\text { Data with } 10 \mathrm{~cm} \\
\text { standard deviation }\end{array}$ \\
\hline Nave pillar thickness & $\mathrm{y}$ & 1.62 & 5.2 & 0.7 & 2.8 & 0.9 & 5.1 & 5.4 & 0.8 & 1.0 & 5.0 & 5 & 0.324 & $\begin{array}{l}\text { Measurements only in } \\
\text { relevant places }\end{array}$ \\
\hline Nave pillar thickness & $\mathrm{x}$ & 1.77 & 5.7 & 0.8 & 3.0 & 0.9 & 5.6 & 5.9 & 0.9 & 1.1 & 5.5 & 5.5 & 0.322 & $\begin{array}{l}20 \mathrm{~cm} \text { difference } \\
\text { between measurements. } \\
\text { but the majority of } \\
\text { data approaches the } \\
\text { arithmetic mean }\end{array}$ \\
\hline $\begin{array}{l}\text { Nave: wall-pillar width } \\
\text { (gallery level) }\end{array}$ & $\mathrm{x}$ & 0.7 & 2.2 & 0.3 & 1.2 & 0.4 & 2.2 & 2.3 & 0.4 & 0.4 & 2.2 & 2 & 0.350 & $\begin{array}{l}15 \mathrm{~cm} \text { difference } \\
\text { between measurements. } \\
\text { but the majority of } \\
\text { data approaches the } \\
\text { arithmetic mean }\end{array}$ \\
\hline $\begin{array}{l}\text { Southern aisle: wall } \\
\text { thickness }\end{array}$ & $\mathrm{y}$ & 0.94 & 3.0 & 0.4 & 1.6 & 0.5 & 3.0 & 3.2 & 0.5 & 0.6 & 2.9 & 3 & 0.313 & $\begin{array}{l}\text { Clear measurement. } \\
\text { similar data in each bay }\end{array}$ \\
\hline $\begin{array}{l}\text { Southern aisle: wall- } \\
\text { pillar thickness }\end{array}$ & $\mathrm{x}$ & 1.29 & 4.1 & 0.6 & 2.2 & 0.7 & 4.1 & 4.3 & 0.7 & 0.8 & 4.0 & 4 & 0.323 & $\begin{array}{l}\text { Clear measurement. } \\
\text { similar data in each bay }\end{array}$ \\
\hline Apse: wall thickness & $\mathrm{y}$ & 1.03 & 3.3 & 0.4 & 1.8 & 0.5 & 3.3 & 3.5 & 0.5 & 0.6 & 3.2 & 3 & 0.343 & $\begin{array}{l}\text { Tapering wall. } \\
\text { Thickness is } 0.85- \\
1.22 \mathrm{~m}\end{array}$ \\
\hline $\begin{array}{l}\text { Southern apsidiol: wall } \\
\text { thickness }\end{array}$ & - & 0.85 & 2.7 & 0.4 & 1.5 & 0.4 & 2.7 & 2.9 & 0.4 & 0.5 & 2.6 & 2.5 & 0.340 & $\begin{array}{l}\text { Apse reconstructed } \\
\text { by Möller with high } \\
\text { accuracy. } 4 \mathrm{~cm} \\
\text { difference between } \\
\text { measurements }\end{array}$ \\
\hline $\begin{array}{l}\text { Northern apsidiol: wall } \\
\text { thickness }\end{array}$ & - & 0.84 & 2.7 & 0.4 & 1.4 & 0.4 & 2.7 & 2.8 & 0.4 & 0.5 & 2.6 & 2.5 & 0.336 & Clear measurement \\
\hline $\begin{array}{l}\text { Nave: window width in } \\
\text { bay no. } 1 \text {. inside }\end{array}$ & $\mathrm{x}$ & 1.03 & 3.3 & 0.4 & 1.8 & 0.5 & 3.3 & 3.5 & 0.5 & 0.6 & 3.2 & 3 & 0.343 & $\begin{array}{l}\text { Window perfectly in } \\
\text { the middle of the bay } \\
\text { wall }\end{array}$ \\
\hline $\begin{array}{l}\text { Nave: window width in } \\
\text { bay no. } 1 \text {. outside }\end{array}$ & $\mathrm{x}$ & 1.77 & 5.7 & 0.8 & 3.0 & 0.9 & 5.6 & 5.9 & 0.9 & 1.1 & 5.5 & 5.5 & 0.322 & $\begin{array}{l}\text { Window in the middle } \\
\text { of the bay wall (with } 6 \\
\mathrm{~cm} \text { difference) }\end{array}$ \\
\hline $\begin{array}{l}\text { Nave: window width in } \\
\text { bay no. } 2 \text {. inside }\end{array}$ & $\mathrm{x}$ & 0.99 & 3.2 & 0.4 & 1.7 & 0.5 & 3.1 & 3.3 & 0.5 & 0.6 & 3.1 & 3 & 0.330 & $\begin{array}{l}\text { Window in the middle } \\
\text { of the bay wall (with } 5 \\
\text { cm difference) }\end{array}$ \\
\hline $\begin{array}{l}\text { Nave: window width in } \\
\text { bay no. } 2 \text {. outside }\end{array}$ & $\mathrm{x}$ & 1.52 & 4.9 & 0.7 & 2.6 & 0.8 & 4.8 & 5.1 & 0.8 & 0.9 & 4.7 & 4.5 & 0.338 & $\begin{array}{l}\text { Window in the middle } \\
\text { of the bay wall (with } 6 \\
\mathrm{~cm} \text { difference) }\end{array}$ \\
\hline $\begin{array}{l}\text { Nave: window width in } \\
\text { bay no. } 3 \text {. inside }\end{array}$ & $\mathrm{x}$ & 1.36 & 4.4 & 0.6 & 2.3 & 0.7 & 4.3 & 4.6 & 0.7 & 0.8 & 4.2 & 4.5 & 0.302 & $\begin{array}{l}\text { Window in the middle } \\
\text { of the bay wall (with } \\
2.5 \mathrm{~cm} \text { difference) }\end{array}$ \\
\hline
\end{tabular}




\begin{tabular}{|c|c|c|c|c|c|c|c|c|c|c|c|c|c|c|}
\hline $\begin{array}{l}\text { Nave: window width in } \\
\text { bay no. } 3 \text {. outside }\end{array}$ & $\mathrm{x}$ & 1.46 & 4.7 & 0.6 & 2.5 & 0.8 & 4.6 & 4.9 & 0.7 & 0.9 & 4.5 & 4.5 & 0.324 & $\begin{array}{l}\text { Window in the middle } \\
\text { of the bay wall (with } 1.5 \\
\mathrm{~cm} \text { difference) }\end{array}$ \\
\hline $\begin{array}{l}\text { Nave: window width in } \\
\text { bay no. } 4 \text {. inside }\end{array}$ & $\mathrm{x}$ & 1.39 & 4.4 & 0.6 & 2.4 & 0.7 & 4.4 & 4.7 & 0.7 & 0.9 & 4.3 & 4.5 & 0.308 & $\begin{array}{l}\text { Window in the middle } \\
\text { of the bay wall (with } 4 \\
\text { cm difference) }\end{array}$ \\
\hline $\begin{array}{l}\text { Nave: window width in } \\
\text { bay no. } 4 \text {. outside }\end{array}$ & $\mathrm{x}$ & 1.41 & 4.5 & 0.6 & 2.4 & 0.7 & 4.5 & 4.7 & 0.7 & 0.9 & 4.3 & 4.5 & 0.313 & $\begin{array}{l}\text { Window in the middle } \\
\text { of the bay wall (with } 8 \\
\mathrm{~cm} \text { difference) }\end{array}$ \\
\hline $\begin{array}{l}\text { Southern aisle: window } \\
\text { width in bay no. } 1 . \\
\text { inside }\end{array}$ & $\mathrm{x}$ & 1.04 & 3.3 & 0.5 & 1.8 & 0.5 & 3.3 & 3.5 & 0.5 & 0.6 & 3.2 & 3 & 0.347 & $\begin{array}{l}\text { Window in the middle } \\
\text { of the bay wall (with } \\
2.5 \mathrm{~cm} \text { difference). The } \\
\text { only window remaining } \\
\text { from the aisles. }\end{array}$ \\
\hline $\begin{array}{l}\text { Southern aisle: window } \\
\text { width in bay no. } 1 . \\
\text { outside }\end{array}$ & $\mathrm{x}$ & 1.04 & 3.3 & 0.5 & 1.8 & 0.5 & 3.3 & 3.5 & 0.5 & 0.6 & 3.2 & 3 & 0.347 & $\begin{array}{l}\text { The only window } \\
\text { remaining from the } \\
\text { aisles }\end{array}$ \\
\hline
\end{tabular}

still widely researched (Kidson, 2008; Bork, 2011; GilLópez, 2012; Ginovart et al., 2013; Murray, 2014; Bork, 2014a; 2014b; Wirth, 2015; Dragović et al., 2019).

The present paper is based on the detection of simple numerical proportions of dimensions of the church of Zsámbék. The analysis is not directly intending to deduce the original medieval design methods but to collect data for detecting proportions in the plan. There are also research projects with similar approaches or perspectives from recent decades (Fernie, 1990; Hiscock, 2000; Zenner, 2002; Addiss, 2002; den Hartog, 2014; Ginovart et al., 2018). The proportions were identified by calculating data with SI units (measured in meters), and experiments were carried out for converting the dimensions into adequate foot units.

\subsection{Calculation of units}

The question of medieval unit systems was also taken into consideration during the study. In various other cases of geometrical analysis, scholars also found it important to detect medieval units (Fernie, 1990; Murray, 2002; Masini et al., 2004). In Hungary, some etalons remained from the 18 th century built in the walls of town halls, such as the fathom etalon in the old town hall of Bratislava. In Hans Hammer's sketchbook from the 15th century, there are some drawings of unit systems (Hoppe, 1994).

The most probable unit used by medieval builders was the foot, which correspondents to 12 inches and 1/12 of a fathom. It is not known which kind (or kinds) of foot unit was used at the construction of the Premonstratensian abbey of Zsámbék in the 13th century. Experiments were carried out to assess if the measured dimensions of the church fitted to some well-known fathom, or foot and inch units. These were the Master Mason Fathom (2.3 m), Buda Ell (0.584 m), Hungarian Fathom (1.896 m), and two types of Hungarian Foot $(0.316 \mathrm{~m}$ and $0.297 \mathrm{~m})$, that could have been used in Hungarian constructions since the Middle Ages (Bogdán, 1978; 1987) (Part II in Table 1). While both the noble family who donated the domain and the Premonstratensian order had French origins, French medieval units such as Toise (1.959 m), French Fathom (1.624 $\mathrm{m})$, French Foot (0.324 m) also seemed worth considering. In Part II of Table 1, the numbers of units (dimension/historical unit) were calculated. The integers $(+/-1 \mathrm{~mm})$ and halves were indicated in red. The results of these calculations were not satisfactory, as none of these units convincingly fitted the dimensions of the church. The percentage of adequate (red) numbers did not exceed $50 \%$.

The calculation was repeated with an inverse logic: the measured dimensions were divided with integers, which resulted in quotients approaching foot units we called quasi feet (Part III in Table 1).

These values, just like historical foot units, measure a rather wide range between 29 and 35 centimeters. There is no clear evidence of any particular foot unit used by 13th-century master masons in Hungary; however, two medieval Hungarian foot units are known, measuring 0.297 and 0.3126 centimeters (Royal foot). Still, it is possible that different local foot units were in use in different parts of the country; also, foreign masters could have used units of their home countries. Moreover, in Hans Hammer's sketchbook on page 1 recto we can find clear evidence, that several foot and inch units were used simultaneously in the practice of the very same workshop on the same building site (Hoppe, 1994). Hammer used the terms 'Alte' (old or big), 'Rechte' (right), 'Junge' (young or small), 
'noch junger' (younger or smaller) to describe them. It is also worth considering that some non-standardised units were applied for tracing on site. Some architectural elements such as the size of joint pieces of pillars or vaulting ribs obviously required high accuracy, so standardised units must have been used for their design. In other cases, however, like the tracing of wall thicknesses or even the full length and width of a building or room, proportion could be more important. In such cases it is possible, that the masters did not use any particular measuring rod, but simply used their own foot instead for example. Hans Hammer, while explaining the previous rather complicated unit system to be used for architectural planning, explicitly suggests using the size of the actual human foot as a starting point (Hoppe, 1994).

\section{Results}

Based on the measurements, a series of numerical ratios can be calculated concerning the geometry of the whole church as well as its details. In each case, we used two different approaches to estimate the proportions the masters may have intended to use. Primarily, we calculated the ratios of the actual dimensions measured on-site in meters (Part I in Table 1). In the second, we first deduced a speculative length for the object in question rounded to full or half feet and recalculated the ratio. This second approach supposes a notable, but still not significant inaccuracy of the tracing and building process, which is usually within the margin of $5 \%$. This explains the two different ratios calculated for the very same feature presented in Figs. 7-9 and Table 2.

\subsection{General observations of proportions}

Often, the actual proportions measured in SI units did not fit those speculated in feet. For example, in the case of the width-length proportion of the nave bays between pillars (Fig. 7 (a)), the actual sizes are $5.44 \mathrm{~m}$ and 3.25 meters. The ratio is 1:0.5974, remarkably close to 5:3, which would suggest a rather plausible proportion to be used by medieval architects. Still, while trying to divide the measured data by 5 and 3 , or their multiples $(10,15$ or 20 and 6,9 or 12) we do not get results that would be close to any known fathom or foot units. If we try to express the measured lengths in full feet, $5.44 \mathrm{~m}$ would be closest 18 feet, while $3.25 \mathrm{~m}$ would be closest to 10 feet. (It is important to note, that the foot units in both calculations are slightly different, 0.302 and 0.325 ). It is again plausible that the builder intended to draw up a bay 18 feet wide and 10 feet long, the ratio of these measures, however, would be 9:5, not 5:3.
This means that the calculated proportions can be significantly influenced by the units. In some of the cases, calculations rounded to full feet, while considering smaller alterations as the results of inaccuracy, seemed to result in more sophisticated ratios. 1:1 ratio is the most representative example. In other cases, however, such as the dimensions of the nave pillars, these alterations have to be considered deliberate. The side parallel to the main axis is somewhat larger than the one measured perpendicularly, as the profile of the pillar follows the structural logic of the vaulting ribs. In this case, a 10:11 ratio also correspondents to a sizing of 5' and 5.5' (Fig. 8 (h)). These pillars were so precisely carved, and our laser scan survey was also sufficiently accurate, that the minor proportions of the section of these pillars were also calculated in inches. Thus, although the original units are highly uncertain (as was described previously), efforts for seeking them are entirely adequate in similar researches.

Another result of the calculation shows that some ratios appeared more frequently than others. These were 1:1, 1:2, 2:3 and 3:4, and 3:5 (Table 2). We have no clear evidence that all of these were applied deliberately, but due to their simplicity and in some cases, their coherence with Pythagorean triples, suggests that they could represent one of the basic geometrical concepts of planning.

During the calculations, it appeared that the ratios of spaces (Part I in Table 2) seemed more reasonable, but the ratios between spins and structure thicknesses (Part II in Table 2) were too complicated and seemed further from reality. This may indicate that wall and pillar thicknesses were not calculated according to numerical ratios, but that other logic was applied by medieval master masons in their design. In Lorenz Lechler's Unterweisung from 1615, the master suggested several numerical ratios, as rules to build a decent chancel (Shelby and Mark, 1979; Sztanekné Apai, 1980). For the ratio of the wall thickness and the width of the chancel, he suggested 1:10. In Zsámbék, such numerical ratios were not found. However, Lechler also suggests that when defining the wall thickness, the strength of the building material used has to be taken into account, so an alteration of \pm 3 inches can be applied (Shelby and Mark, 1979; Hoppe 1984). This suggests that structural considerations may play a role in defining wall thicknesses, which explains why the measures in case of Zsámbék are not unified, even though mostly close to 3 feet. Still, the design methods of structural thicknesses could change from the 13th to the 15th century, and the design methods could vary by lodges or masters. 
a

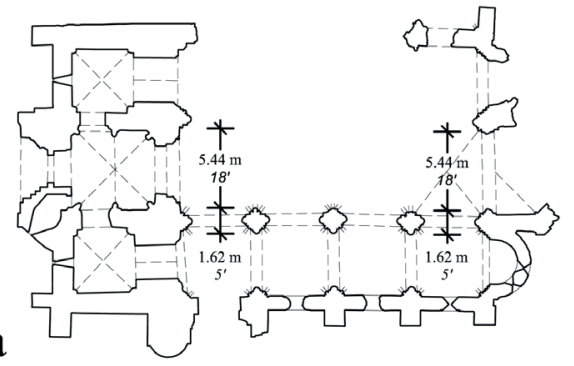

Nave pillar thickness and width

Actual ratio:

Speculated ratio:

$1: 3.3580$

$5: 18$

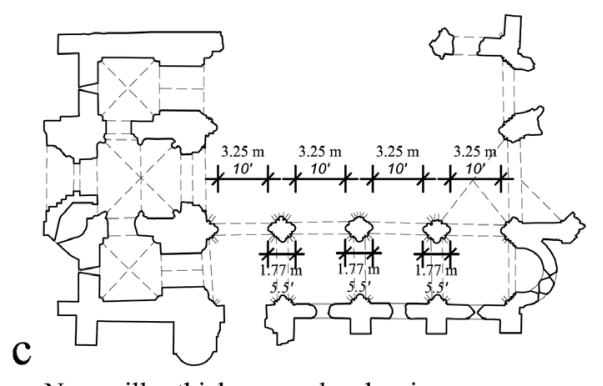

Nave pillar thickness and arch spins

Actual ratio:

$1: 1.8361$

Speculated ratio:

$11: 20(\approx 1: 2)$

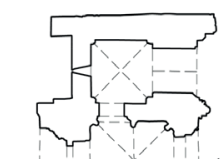

25

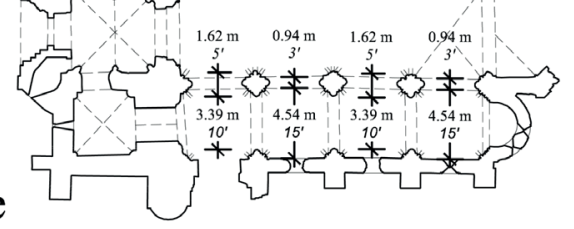

$\mathrm{S}$ aisle pillar thickness and width

Actual ratio (pillar thickness and spin): $1: 2.0925$

Speculated ratio (pillar thickness and spin): $\quad 1: 2$

Actual ratio (wall thickness and width): $1: 4.8297$

Speculated ratio (wall thickness and width): $\quad 1: 5$
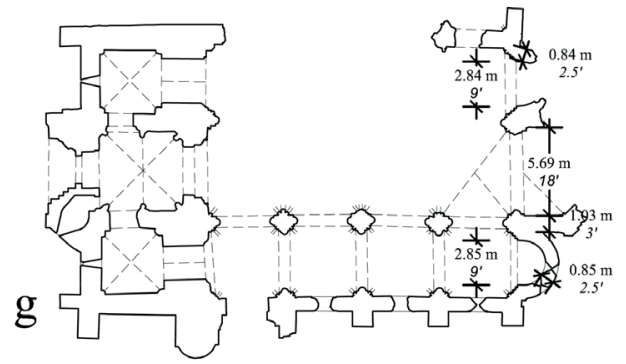

Actual ratio, Apse wall thickness - width: $1: 5.5242$ Speculated ratio, Apse wall thickness - width: $\quad$ 1:6 Actual ratio, Apsidiols wall thickness - $\emptyset: \quad 1: 3.3$ Speculated ratio, Apsidiols wall thickness - Ø: 5:18

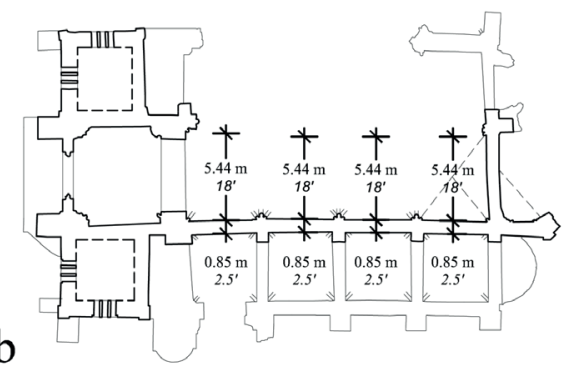

Nave wall thickness and width (gallery level)

Actual ratio:

$1: 6.4$

Speculated ratio:

$5: 36(\approx 1: 7)$

d

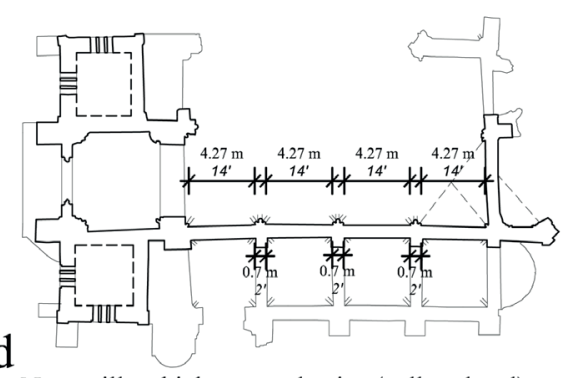

Nave pillar thickness and spins (gallery level)

Actual ratio:

$1: 6.1$

Speculated ratio:

$1: 7$
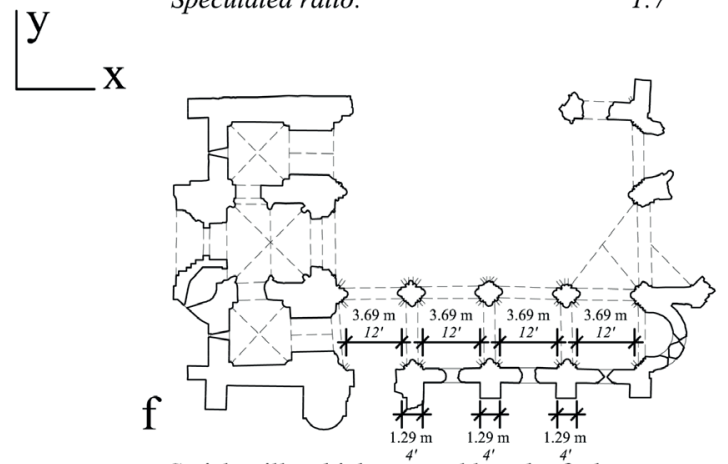

$\mathrm{S}$ aisle pillar thickness and length of a bay

Actual ratio:

$1: 2.8604$

Speculated ratio:

$1: 3$

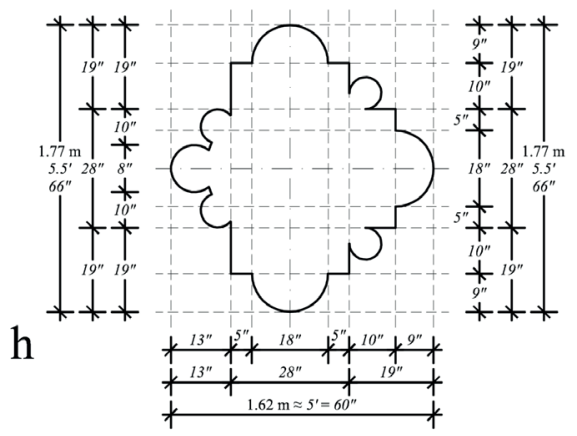

Width - length of nave pillar

Actual ratio, width - length:

$1: 1.0925$

Speculated ratio, width - length:

10:11

Fig. 8 Actual ratios calculated by measured data in SI and speculated ratios by the calculation of quasi-foot unit. Proportions of structure thicknesses and spaces, Part II in Table 2 (authors' drawing) 
Table 2 Actual ratios calculated by measured data in SI and speculated ratios by the calculation of quasi-foot unit

\begin{tabular}{|c|c|c|c|c|}
\hline \multirow{21}{*}{$\begin{array}{l}\text { PART I } \\
\text { PROPORTIONS } \\
\text { OF SPACES }\end{array}$} & TYPE OF DIMENSIONS & UNIT & DIMENSIONS & RATIO \\
\hline & \multirow{2}{*}{ Width - length of nave bays (Fig. 7 a) } & meter & $5.44 \mathrm{~m}: 3.25 \mathrm{~m}$ & $1: 0.5974$ \\
\hline & & foot & $18^{\prime}: 10^{\prime}$ & $9: 5(\sim 3: 5)$ \\
\hline & \multirow{2}{*}{ Width - length of nave bays (axes) (Fig. 7 b) } & meter & $6.5 \mathrm{~m}: 5.0 \mathrm{~m}$ & $1: 0.7692$ \\
\hline & & foot & $21^{\prime}: 16^{\prime}$ & $21: 16(\sim 4: 3)$ \\
\hline & \multirow{2}{*}{$\begin{array}{l}\text { Width - length of Southern aisle bays (between walls and } \\
\text { pillar cores) (Fig. } 7 \text { c) }\end{array}$} & meter & $4.54 \mathrm{~m}: 3.7 \mathrm{~m}$ & $1: 0.8149$ \\
\hline & & foot & $15^{\prime}: 12^{\prime}$ & $5: 4$ \\
\hline & \multirow{2}{*}{ Width - length of Southern aisle bays (axes) (Fig. 7 d) } & meter & $5.33 \mathrm{~m}: 5.0 \mathrm{~m}$ & $1: 0.9380$ \\
\hline & & foot & $18^{\prime}: 16^{\prime}$ & $9: 8(\sim 11: 10)$ \\
\hline & \multirow{2}{*}{ Width of nave and Southern aisle (Fig. 7 e) } & meter & $5.44 \mathrm{~m}: 4.54 \mathrm{~m}$ & $1: 0.8345$ \\
\hline & & foot & $18^{\prime}: 15^{\prime}$ & $6: 5$ \\
\hline & Width of nave and Southern aisle (axes) & meter & $6.5 \mathrm{~m}: 5.33 \mathrm{~m}$ & $1: 0.82$ \\
\hline & Width of apse and Southern apsidiol (axes) (Fig. 7 f) & foot & $21^{\prime}: 18^{\prime}$ & $7: 6$ \\
\hline & \multirow{2}{*}{ Width of nave and Northern aisle (Fig.7/e) } & meter & $5.44 \mathrm{~m}: 4.57 \mathrm{~m}$ & $1: 0.8400$ \\
\hline & & foot & $18^{\prime}: 15^{\prime}$ & $6: 5$ \\
\hline & Width of nave and Northern aisle (axes) & meter & $6.5 \mathrm{~m}: 5.4 \mathrm{~m}$ & $1: 0.8307$ \\
\hline & Width of apse and Northern apsidiol (axes) (Fig. 7 f) & foot & $21^{\prime}: 18^{\prime}$ & $7: 6$ \\
\hline & \multirow{2}{*}{ Width of apse and Southern apsidiol (Fig. 7 e) } & meter & $5.69 \mathrm{~m}: 2.86 \mathrm{~m}$ & $1: 0.5026$ \\
\hline & & foot & $18^{\prime}: 9^{\prime}$ & $2: 1$ \\
\hline & \multirow{2}{*}{ Width of apse and Northern apsidiol (Fig. 7 e) } & meter & $5.69 \mathrm{~m}: 2.92 \mathrm{~m}$ & $1: 0.5131$ \\
\hline & & foot & $18^{\prime}: 9^{\prime}$ & $2: 1$ \\
\hline \multirow{23}{*}{$\begin{array}{l}\text { PART II } \\
\text { PROPORTIONS } \\
\text { OF } \\
\text { STRUCTURE } \\
\text { THICKNESSES } \\
\text { AND SPACES }\end{array}$} & TYPE OF DIMENSIONS & UNIT & DIMENSIONS & RATIO \\
\hline & \multirow{2}{*}{ Nave: pillar thickness and width (Fig. 8 a) } & meter & $1.62 \mathrm{~m}: 5.44 \mathrm{~m}$ & $1: 3.3580$ \\
\hline & & foot & $5^{\prime}: 18^{\prime}$ & $5: 18$ \\
\hline & \multirow{2}{*}{ Nave: wall thickness and width (gallery level) (Fig. 8 b) } & meter & $0.85 \mathrm{~m}: 5.44 \mathrm{~m}$ & $1: 6.4$ \\
\hline & & foot & $2.5^{\prime}: 18^{\prime}$ & $5: 36(\sim 1: 7 ?)$ \\
\hline & \multirow{2}{*}{ Nave: pillar thickness and arch spins (Fig.8 c) } & meter & $1.77 \mathrm{~m}: 3.25 \mathrm{~m}$ & $1: 1.8361$ \\
\hline & & foot & $5.5^{\prime}: 10^{\prime}$ & $11: 20(\sim 1: 2 ?)$ \\
\hline & \multirow{2}{*}{ Nave: pillar thickness and spins (gallery level) (Fig. 8 d) } & meter & $0.7 \mathrm{~m}: 4.27 \mathrm{~m}$ & $1: 6.1$ \\
\hline & & foot & $2^{\prime}: 14^{\prime}$ & $1: 7$ \\
\hline & \multirow{2}{*}{ Southern aisle: wall thickness and width (Fig. 8 e) } & meter & $0.94 \mathrm{~m}: 4.54 \mathrm{~m}$ & $1: 4.8297$ \\
\hline & & foot & $3^{\prime}: 15^{\prime}$ & $1: 5$ \\
\hline & \multirow{2}{*}{ Southern aisle: pillar thickness and width (Fig. 8 e) } & meter & $1.62 \mathrm{~m}: 3.39 \mathrm{~m}$ & $1: 2.0925$ \\
\hline & & foot & $5^{\prime}: 10^{\prime}$ & $1: 2$ \\
\hline & \multirow{2}{*}{ Southern aisle: pillar thickness and length of a bay (Fig. $8 \mathbf{f}$ ) } & meter & $1.29 \mathrm{~m}: 3.69 \mathrm{~m}$ & $1: 2.8604$ \\
\hline & & foot & $4^{\prime}: 12^{\prime}$ & $1: 3$ \\
\hline & \multirow{2}{*}{ Apse: wall thickness and width (Fig. 8 g) } & meter & $1.03 \mathrm{~m}: 5.69 \mathrm{~m}$ & $1: 5.5242$ \\
\hline & & foot & $3^{\prime}: 18^{\prime}$ & $1: 6$ \\
\hline & \multirow{2}{*}{ Southern apsidiol: wall thickness and diameter (Fig. 8 g) } & meter & $0.85 \mathrm{~m}: 2.85 \mathrm{~m}$ & $1: 3.3529$ \\
\hline & & foot & $2.5^{\prime}: 9^{\prime}$ & $5: 18$ \\
\hline & \multirow{2}{*}{ Northern apsidiol: wall thickness and diameter (Fig. 8 g) } & meter & $0.84 \mathrm{~m}: 2.84 \mathrm{~m}$ & $1: 3.3809$ \\
\hline & & foot & $2.5^{\prime}: 9^{\prime}$ & $5: 18$ \\
\hline & \multirow{2}{*}{ Width - length of nave pillars (Fig. 8 h) } & meter & $1.62 \mathrm{~m}: 1.77 \mathrm{~m}$ & $1: 1.0925$ \\
\hline & & foot & $5^{\prime}: 5.5^{\prime}$ & $10: 11$ \\
\hline
\end{tabular}




\begin{tabular}{|c|c|c|c|c|}
\hline \multirow{21}{*}{$\begin{array}{l}\text { PART III } \\
\text { PROPORTIONS } \\
\text { OF THE NAVE } \\
\text { WINDOWS }\end{array}$} & TYPE OF DIMENSIONS & UNIT & DIMENSIONS & RATIO \\
\hline & \multirow{2}{*}{$\begin{array}{l}\text { Nave window of bay no. 1. inside: } \\
\text { width of window and side walls (Fig. 9) }\end{array}$} & meter & $1.62 \mathrm{~m}: 1.03 \mathrm{~m}: 1.62 \mathrm{~m}$ & $1: 0.6358: 1$ \\
\hline & & foot & $5^{\prime}: 3^{\prime}: 5^{\prime}$ & $5: 3: 5$ \\
\hline & \multirow{2}{*}{$\begin{array}{l}\text { Nave window of bay no. 1. outside: } \\
\text { width of window and side walls (Fig. 9) }\end{array}$} & meter & $1.19 \mathrm{~m}: 1.77 \mathrm{~m}: 1.19 \mathrm{~m}$ & $1: 1.4873: 1$ \\
\hline & & foot & $3.5^{\prime}: 5.5^{\prime}: 3.5^{\prime}$ & $7: 11: 7(\sim 3: 5: 3 ?)$ \\
\hline & \multirow{2}{*}{$\begin{array}{l}\text { Nave window of bay no. 2. inside: } \\
\text { width of window and side walls (Fig. 9) }\end{array}$} & meter & $1.64 \mathrm{~m}: 0.99 \mathrm{~m}: 1.64 \mathrm{~m}$ & $1: 0.6036: 1$ \\
\hline & & foot & $5^{\prime}: 3^{\prime}: 5^{\prime}$ & $5: 3: 5$ \\
\hline & \multirow{2}{*}{$\begin{array}{l}\text { Nave window of bay no. 2. outside: } \\
\text { width of window and side walls (Fig. 9) }\end{array}$} & meter & $1.32 \mathrm{~m}: 1.52 \mathrm{~m}: 1.32 \mathrm{~m}$ & $1: 1.1515: 1$ \\
\hline & & foot & $4.5^{\prime}: 4.5^{\prime}: 4.5^{\prime}$ & $1: 1: 1$ \\
\hline & \multirow{2}{*}{$\begin{array}{l}\text { Nave window of bay no. 3. inside: } \\
\text { width of window and side walls (Fig. 9) }\end{array}$} & meter & $1.45 \mathrm{~m}: 1.36 \mathrm{~m}: 1.45 \mathrm{~m}$ & $1: 0.9379: 1$ \\
\hline & & foot & $4.5^{\prime}: 4.5^{\prime}: 4.5^{\prime}$ & $1: 1: 1$ \\
\hline & \multirow{2}{*}{$\begin{array}{l}\text { Nave window of bay no. 3. outside: } \\
\text { width of window and side walls (Fig. 9) }\end{array}$} & meter & $1.35 \mathrm{~m}: 1.46 \mathrm{~m}: 1.35 \mathrm{~m}$ & $1: 1.0814: 1$ \\
\hline & & foot & $4.5^{\prime}: 4.5^{\prime}: 4.5^{\prime}$ & $1: 1: 1$ \\
\hline & \multirow{2}{*}{$\begin{array}{l}\text { Nave window of bay no. 4. inside: } \\
\text { width of window and side walls (Fig. 9) }\end{array}$} & meter & $1.44 \mathrm{~m}: 1.39 \mathrm{~m}: 1.44 \mathrm{~m}$ & $1: 0.9652: 1$ \\
\hline & & foot & $4.5^{\prime}: 4.5^{\prime}: 4.5^{\prime}$ & $1: 1: 1$ \\
\hline & \multirow{2}{*}{$\begin{array}{l}\text { Nave window of bay no. 4. outside: } \\
\text { width of window and side walls (Fig. 9) }\end{array}$} & meter & $1.37 \mathrm{~m}: 1.41 \mathrm{~m}: 1.37 \mathrm{~m}$ & $1: 1.0291: 1$ \\
\hline & & foot & $4.5^{\prime}: 4.5^{\prime}: 4.5^{\prime}$ & $1: 1: 1$ \\
\hline & \multirow{2}{*}{$\begin{array}{l}\text { Southern aisle window in the Eastern bay. inside: width of } \\
\text { window and side walls (Fig. 9) }\end{array}$} & meter & $1.33 \mathrm{~m}: 1.04 \mathrm{~m}: 1.33 \mathrm{~m}$ & $1: 0.7819: 1$ \\
\hline & & foot & $4^{\prime}: 3^{\prime}: 4^{\prime}$ & $4: 3: 4$ \\
\hline & \multirow{2}{*}{$\begin{array}{l}\text { Southern aisle window in the Eastern bay. outside: width of } \\
\text { window and side walls (Fig. 9) }\end{array}$} & meter & $1.33 \mathrm{~m}: 1.04 \mathrm{~m}: 1.33 \mathrm{~m}$ & $1: 0.7819: 1$ \\
\hline & & foot & $4^{\prime}: 3^{\prime}: 4^{\prime}$ & $4: 3: 4$ \\
\hline
\end{tabular}

\subsection{Proportions of the nave windows}

Lorenz Lechler also noted some rules concerning other proportions (Shelby and Mark, 1979). One of these is comparable with the present study, namely the ratio of the width of windows compared to the width of the side walls. Lechler suggested 1:2:1 or 1:3:1 ratios (Sztanekné Apai, 1980). As the Unterweisung represents, this type of ratio surely represented an important part of the medieval design process in the 15 th century, and according to our results, they were also adequate in the 13th century as well. Late Gothic architecture, of course, is characterised by much thinner structures and larger openings than the late Romanesque or early Gothic ones in Zsámbék. It is still worth examining the relationship of sidewalls and windows as it could have been a notable design aspect a few centuries earlier already.

In Zsámbék, one window of the Southern aisle and the four windows of the Southern nave wall have remained. The windows of the central nave are quite heterogeneous in masonry techniques, geometry and mouldings. Möller supposed that two of these windows were originally built in the first construction period, but then they were later placed in their current position during the third period after the Mongol invasion (Möller, 1925). The study of the proportions of these windows can provide new contributions to this questioned aspect of 13th-century construction.

The widths of the bays and windows are presented in Fig. 9 and Part III in Table 2.

In bay no. 3 and no. 4 , the ratio is considered as 1:1:1 from both outside and inside. In bay no. 2 the outside ratio is also speculated as 1:1:1, but the inside one approaches $5: 3: 5$. In bay no. 1 , the proportion was approximately 3.5 : $5.5: 3.5$ from outside and 5:3:5 from inside (Fig. 9).

Summarising these results, the medieval concept of the nave window design of bay no. 1 was likely to follow the rule that the outside proportions of the window width were the inverse of those inside. In bays 3 and 4, the ratio is approximately the same both outside and inside: 1:1:1. Between them, bay 2 has the 1:1:1 outside ratio matching with bays 3 and 4 , but the inside ratio of 5:3:5 rather matches bay no. 1 . Whether the direction of the construction is presumed from East to West or vice versa, it seems that the concept of window proportioning was changed during the building of bay no. 2 . The ratios and the width 


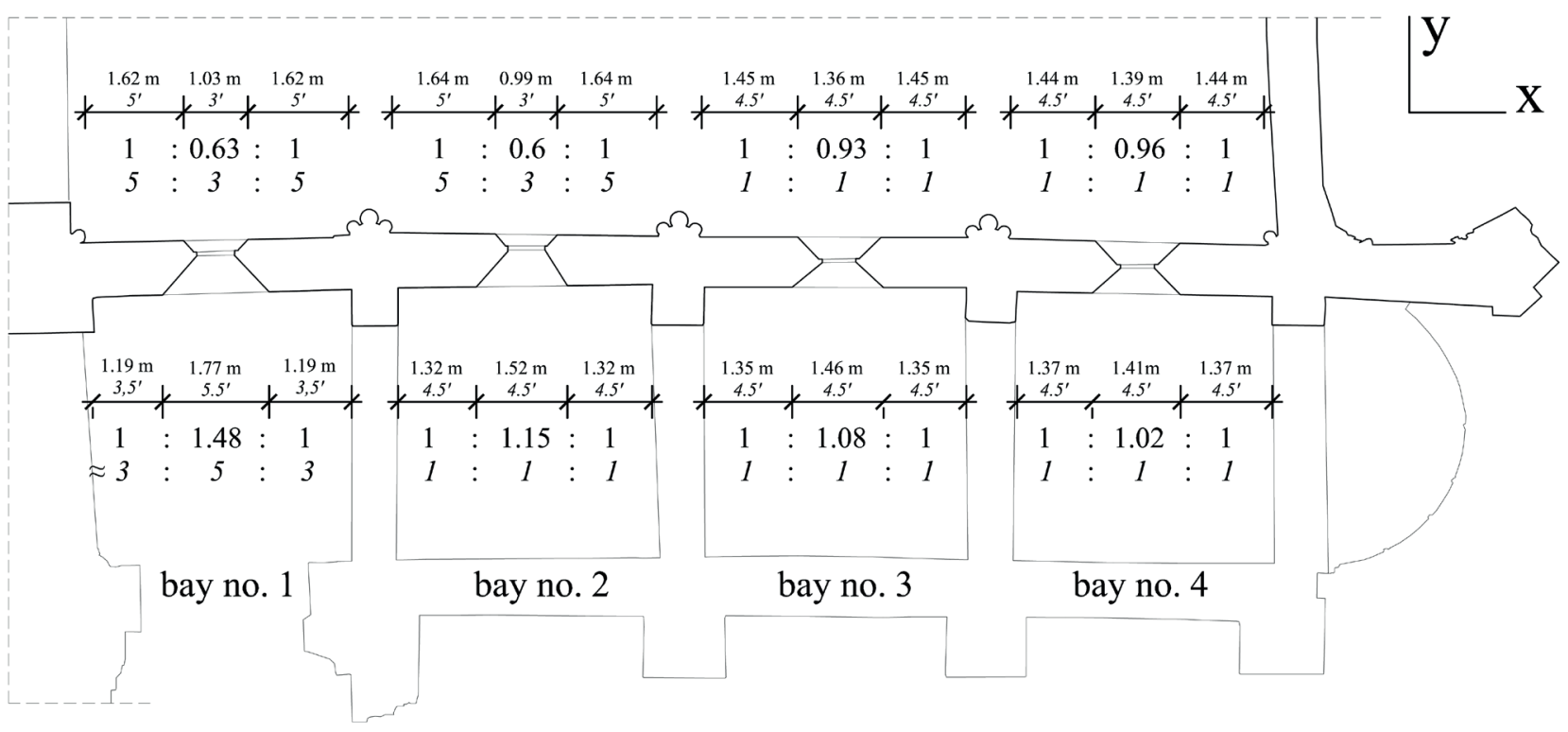

Fig. 9 Proportions of the nave windows (authors' drawing)

of the window were reconsidered, and bay no. 2 became a hybrid of the old and the new concept. It is important to note that the two western windows of the nave (in bays 1 and 2) were built with different masonry techniques. While the two Eastern ones (in bay 3 and 4) were built from carved ashlars fitting to the masonry texture of the walls by lines and levels; the other two (nos. 1 and 2) were worked out of larger jambs that joined less regularly to the wall masonry. Nevertheless, despite all the heterogeneous features of the windows, and according to the proportions, the whole nave wall is much more likely to represent a homogenous construction period with only minor reconsiderations in the detail design, but no major changing of overall concepts.

\section{Conclusion}

In addition to the high standard results of the research of Zsámbék church from recent decades, the $13^{\text {th }}$-century history of the construction was further reviewed in the paper. Our research method represented a rather new approach in order to reveal new information about the history of the construction and the possible design techniques of the medieval builders. The method was based on the terrestrial laser scanning of the ruins. The point cloud was appropriate for the measurements of dimensions of the plan in order to detect numerical ratios and proportioning systems. Several ratios were found, including the sequence of the nave windows. The proportions of the nave windows showed that the detail design concept was changed during the progress of the basilica's construction, but this did not suggest any significant borders of construction periods. It is more likely that the same masters or lodge continued with the same plan, but they seemed to improve the proportioning logic according to their experiences from the ongoing construction.

It is also rather obvious, that in accordance with the information from written sources from the late Gothic period, several units were used concurrently while building this 13th-century construction; some of them perhaps not standardized. Hence the attempt to find a characteristic unit on which the design was based was unsuccessful. This underlines that however significant or important the proportions of a building are, the question of particular units used in the design process has to be dealt with rather carefully.

\section{Acknowledgement}
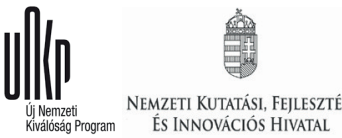

Supported by the ÚNKP19-3 New National Excellence Innovation and Technology. 


\section{References}

Achille, C., Fassi, F., Mandelli, A., Fiorillo, F. (2018) "Surveying cultural heritage: summer school for conservation activities", Applied Geomatics, 10(4), pp. 579-592. https://doi.org/10.1007/s12518-018-0225-3

Ackerman, J. S. (1949) "AArs sine scientia nihil est' - Gothic theory of architecture at the Cathedral of Milan", The Art Bulletin, 31(2), pp. 84-111. https://doi.org/10.2307/3047224

Adams, A. T. (2016) "Drawing for Understanding: Creating Interpretive Drawings of Historic Buildings", Historic England. [online] Available at: https://historicengland.org.uk/images-books/publications/drawing-for-understanding/ [Accessed: 04 June 2019]

Addiss, J. (2002) "Measure and Proportion in Romanesque Architecture", In: Wu, N. Y. (ed.) Ad Quadratum: The Practical Application of Geometry in Medieval Architecture", Ashgate Publishing, Farnham, UK, pp. 57-81. https://oi.org/10.4324/9781315263373

Antón, D., Pineda, P., Medjdoub, B., Iranzo, A. (2019) "As-Built 3D Heritage City Modelling to Support Numerical Structural Analysis: Application to the Assessment of an Archaeological Remain", Remote Sensing, 11(11), Article number: 1276. https://doi.org/10.3390/rs11111276

Bardoly, I. (2010) "“Igen veszedelmes útra léptünk”: Zsámbék 19331934" ('We stepped to a very dangerous path': Zsámbék 19331934), Műemlékvédelem, 54(3), pp. 189-200. (in Hungarian)

Barnes, C. F. (1972) "The Gothic Architectural Engravings in the Cathedral of Soissons", Speculum, 47(1), pp. 60-64. https://doi.org/10.2307/2851216

Barnes, C. F. (2009) "The Portfolio of Villard de Honnecourt: A New Critical Edition and Color Facsimile", Ashgate Publishing, Farnham, UK.

Bechmann, R. (1991) "Villard de Honnecourt: la pensée technique au XIIIe siecle et sa communication" (Villard de Honnecourt: the technical thinking in the 13th century and its communication), Picard, Paris, France. (in French)

Belgya, A. É. (2014) "A romanikus és gótikus katedrálisok tartószerkezeti vizsgálata" (Structural examination of Romanesque and Gothic Cathedrals), Postgraduate Course Thesis, Budapest University of Technology and Economics. (in Hungarian)

Bogdán, I. (1978) "Magyarországi hossz-és földmértékek a XVI. század végéig" (Length and Land Measures in Hungary till the $16^{\text {th }}$ century), Akadémiai Kiadó, Budapest, Hungary. (in Hungarian)

Bogdán, I. (1987) "Régi magyar mértékek" (Old Hungarian Units), Gondolat Könyvkiadó, Budapest, Hungary. (in Hungarian)

Bogyay, T. (1943) "A jáki apátsági templom és Szent Jakab kápolna" (The abbey of Ják and Saint Jacob Chapel), A Dunántúli Szemle Könyvei, Vol. 220, Martineum Rt., Szombathely, Hungary. (in Hungarian)

Bóna, I. (2008) "Festék- és vakolatminták előzetes vizsgálata a zsámbéki középkori templomromban" (Preliminary examination of paint and coating samples of the medieval ruins of Zsámbék), Mủvészettörténeti Értesítő, 57(1), pp. 95-96. (in Hungarian) https://doi.org/10.1556/MuvErt.57.2008.1.5
Bóna, I. (2009) "Fototechnikai vizsgálatok a zsámbéki középkori romtemplomban" (Phototechnical investigations in the medieval ruins of Zsámbék), In: Tüskés, A. (ed.) Omnis creatura significans, CentrArt Egyesület, Budapest, Hungary, pp. 61-63. (in Hungarian)

Bony, J. (1990) "The Stonework planning of the first Durham master", In: Fernie, E., Crossley, P. (eds.) Medieval Architecture and its Intellectual Context: Studies in Honour of Peter Kidson, The Hambledon Press, London, UK, pp. 19-34.

Bork, R. (2011) "The Geometry of Creation", Architectural Drawing and the Dynamics of Gothic Design, Ashgate Publishing, Farnham, UK.

Bork, R. (2014a) "Dynamic Unfolding and the Conventions of Procedure: Geometric Proportioning Strategies in Gothic Architectural Design", Architectural Histories, 2(1), Part A(14), pp. 1-20. https://doi.org/10.5334/ah.bq

Bork, R. (2014b) "The Geometry of Bourges Cathedral", Architectural Histories, 2(1), Article number 24. https://doi.org/10.5334/ah.bz

Bozóki, L. (2002) "Padányi Bíró Márton veszprémi püspök zsámbéki helyreállítása" (Restoration of Zsámbék by Márton Padányi Bíró, bishop of Veszprém), Műemlékvédelmi Szemle, 12(1), pp. 101112. (in Hungarian).

Bryan, P. (2010) "Metric Survey for Preservation Uses: Past, Present, and Future", APT Bulletin: The Journal of Preservation Technology, 41(4), pp. 25-29.

Branner, R. (1957) "Three Problems from the Villard de Honnecourt Manuscript", The Art Bulletin, 31(1), pp. 61-66. https://doi.org/10.2307/3047684

Branner, R. (1963) "Villard de Honnecourt, Reims and the Origin of Gothic Architectural Drawing", Gazette des Beaux Arts, 61, pp. 129-146.

Bucher, F. (1968) "Design in Gothic Architecture - A Preliminary Assessment", Journal of the Society of Architectural Historians, 27(1), pp. 49-71.

Bucher, F. (1972) "Medieval Architectural Design Methods, 800-1560", Gesta, 11(2), pp. 37-51. https://doi.org/10.2307/766593

Chen, S., Wang, S., Li, C., Hu, Q., Yang, H. (2018) "A Seismic Capacity Evaluation Approach for Architectural Heritage Using Finite Element Analysis of Three-Dimensional Model: A Case Study of the Limestone Hall in the Ming Dynasty", Remote Sensing, 10(6), Article number: 963. https://doi.org/10.3390/rs10060963

Chias, P., Abad, T. (2018) "The Botica or Apothecary in the Monastery of San Lorenzo el Real de El Escorial (Madrid, Spain): Written Sources, Historic Drawings, and New Surveys Applied to Architectural Analysis", Buildings, 8(1), Article number: 4. https://doi.org/10.3390/buildings 8010004

Conant, K. J. (1968) "The after-life of Vitruvius in the Middle Ages", Journal of the Society of Architectural Historians, 27(1), pp. 33-38.

Csemegi, J. (1936) "Tervezés-technikai kérdések a középkori építészetben" (Design methodological questions of medieval architecture), A Magyar Mérnök és Építész Egylet Közlönye, 70, pp. 7-12. (in Hungarian) 
Csemegi, J. (1939) "A jáki apátság temploma" (The abbey of Ják), Vasi Szemle, 6(1-2), pp. 12-37. (in Hungarian)

Csemegi, J. (1953) "A középkori építészet szerkesztési módszerei" (Geometrical construction methods of medieval architecture), Magyar Müvészettörténeti Munkaközösség Évkönyve, Budapest, Hungary, pp. 13-56. (in Hungarian)

Czagány, I. (1985) "A budavári gótika tervezéstechnikai módszerei és összefüggései" (Design methods and relations of the Gothic architecture of Buda Castle), Épités - építészettudomány, 17(3-4), pp. 397-452. (in Hungarian)

Daragó, L. (2010) "A mủemlékvédelem válsága, avagy Zsámbék. Egy mủemlékhelyreállitás elemzése" (The crisis of monument preservation, or Zsámbék. Analysis of a restoration), Építés - építészettudomány, 29(3-4), pp. 389-414. (in Hungarian)

de Jonge, K., Balen, K. (ed.) (2002) "Preparatory Architectural Investigation in the Restoration of Historical Buildings", In: Papers of the international updating course held at the Raymond Lemaire Internation Centre for Conservation, Leuven University Press, Leuven, Belgium.

de Lima, R., Sykora, T., De Meyer, M., Willems, H., Vergauwen, M. (2018) "On Combining Epigraphy, TLS, Photogrammetry, and Interactive Media for Heritage Documentation: The Case Study of Djehutihotep's Tomb in Dayr al-Barsha", In: Sablatnig, R., Wimmer, M. (eds.) Eurographics Workshop on Graphics and Cultural Heritage, The Eurographics Association, Geneva, Switzerland, pp. 225-229.

https://doi.org/10.2312/gch.20181367

den Hartog, E. (2014) "1, 2, 3, 6: Early Gothic Architecture and Perfect Numbers", Architectural Histories, 2(1), Article number: 17. https://doi.org/10.5334/ah.bu

Dercsényi, D., Valter, I., Bozóki, L. (2007) "Zsámbék. Templomrom" (Zsámbék. Church ruins), Tájak, Korok, Múzeumok Egyesület, Budapest, Hungary. (in Hungarian).

Diaz, M., Holzer, S. M. (2019) "The Facade's Dome of the St. Anthony's Basilica in Padua", The International Archives of the Photogrammetry, Remote Sensing and Spatial Information Sciences, 42(2/W11), pp. 481-487. https://doi.org/10.5194/isprs-archives-XLII-2-W11-481-2019

Dragović, M., Čučaković, A., Bogdanović, J., Pejić, M., Srećković, M. (2019) "Geometric Proportional Schemas of Serbian Medieval Raška Churches Based on Štambuk’s Proportional Canon", Nexus Network Journal, 21(1), pp. 33-58. https://doi.org/10.1007/s00004-018-00426-Z

Entz, G. (1959) "Nyugati karzatok románkori építészetünkben" (The question of Western galleries in our Romanesque architecture), Művészettörténeti Értesítő, 8(2-3), pp. 130-142. (in Hungarian).

Entz, G. (1992) "Le séjour en Hongrie de Hans Hammer, futur maître d'œuvre de la cathédrale de Strasbourg" (Stay in Hungary of Hans Hammer, future master of the Cathedral of Strasbourg), Bulletin de la Cathédrale de Strasbourg, 20, pp. 7-10. (in French)

Fehér, I. (2008) "Zsámbék elfeledett falképei. Giovanni Battista Cavalcaselle tanítványának felmérése a premontrei templom falképeiről 1895-ből" (The forgotten wall-paintings of Zsámbék. Survey of the wall-paintings of the Premonstratensian abbey of Giovanni Battista Cavalcaselle's student from 1895), Mủvészettörténeti értesítő, 57(1), pp. 83-94. (in Hungarian) https://doi.org/10.1556/MuvErt.57.2008.1.4
Fehér, K., Halmos, B. (2015) "A középkori építészet szerkesztési módszerei a hazai szakirodalom tükrében" (Architectural design methods of the middle ages by the Hungarian historiography), Építés - építészettudomány, 43(3-4), pp. 237-284. (in Hungarian) https://doi.org/10.1556/096.2015.43.3-4.7

Fehér, K., Halmos, B. (2016) "Középkori szerkesztőmódszerek kutatása Möller István életmúvében" (Research of medieval design methods in the oeuvre of István Möller), Müemlékvédelem, 60(1-2), pp. 86-100. (in Hungarian)

Fehér, K., Szilágyi, B., Bölcskei, A., Halmos, B. (2019) "Pentagons in Medieval Sources and Architecture", Nexus Network Journal, 21(3), pp. 681-703. https://doi.org/10.1007/s00004-019-00450-7

Feilden, B. M. (2003) "Conservation of Historic Buildings", Architectural Press, Linacre House, Jordan Hill, Oxford, UK.

Fejérdy, T. (1998) "Zsámbék, mủemlék helyreállítás" (Zsámbék, monument restoration), Magyar Építőipar, 48(11-12), pp. 311-317. (in Hungarian)

Fernie, E. (1990) "A Beginner's Guide to the Study of Architectural Proportions and the Systems of Length", In: Fernie, E., Crossley, P. (eds.) Medieval Architecture and its Intellectual Context: Studies in Honour of Peter Kidson, The Hambledon Press, London, UK, pp. 229-237.

Fiorani, D. (1996) "Tecniche costruttive murarie medievali" (Building Technology of Medieval Masonries), Il Lazio meridionale, L'Erma di Bretschneider, Rome, Italy. (in Italian)

Fregonese, L., Barbieri, G., Biolzi, L., Bocciarelli, M., Frigeri, A., Taffurelli, L. (2013) "Surveying and Monitoring for Vulnerability Assessment of an Ancient Building", Sensors, 13(8), pp. 9747-9773. https://doi.org/10.3390/s130809747

Gerevich, L. (1971) "Villard de Honnecourt Magyarországon" (Villard de Honnecourt in Hungary), Művészettörténeti értesítő, 20(2), pp. 81-105. (in Hungarian)

Gergelyffy, A. (1958) "A múemlékvédelem múltjából (Henszlmann Imre és a bélapátfalvi templom)" (From the past of monument preservation (Imre Henszlmann and the church of Bélapátfalva)), Mủemlékvédelem, 2(4), pp. 205-210. (in Hungarian)

Gil-López, T. (2012) "The Vault of the Chapel of the Presentation in Burgos Cathedral: 'Divine Canon? No, Cordovan Proportion'", Nexus Network Journal, 14(1), pp. 177-189. https://doi.org/10.1007/s00004-011-0104-2

Ginovart, J. L., Anguera, G. F., Jover, A. C., de Sola-Morales Serra, P. (2013) "Gothic Construction and the Traça of a Heptagonal Apse: The Problem of the Heptagon", Nexus Network Journal, 15(2), pp. 325-348. https://doi.org/10.1007/s00004-013-0152-x

Ginovart, J. L., López-Piquer, M., Urbano-Lorente, J. (2018) "Transfer of Mathematical Knowledge for Building Medieval Cathedrals", Nexus Network Journal, 20(1), pp. 153-172. https://doi.org/10.1007/s00004-017-0359-3

Grilli, E., Remondino, F. (2019) "Classification of 3D Digital Heritage", Remote Sensing, 11(7), Article number: 847. https://doi.org/10.3390/rs11070847

Guzsik, T. (1974a) "A zsámbéki templomrom építéstörténete, építészettörténeti és mủemlékvédelmi vonatkozásai" (The construction history, architectural history and monument preservation of the church ruins of Zsámbék), Doctoral Thesis, Budapest University of Technology. (in Hungarian) 
Guzsik, T. (1974b) "Die bauliche Vorgeschichte der Basilika von Zsámbék" (The construction history of the Basilica of Zsámbék), Periodica Polytechnica Architecture, 18(1-2), pp. 149-170. (in German)

Guzsik, T. (1977) "Mủemlékvédelem Zsámbékon" (Monument preservation in Zsámbék), Építés-Építészettudomány, 9(2-3), pp. 229-246. (in Hungarian)

Guzsik, T. (1979) "Die Werkstattbeziehungen der romanischen Kirche am Zsámbék" (The Workshop Relations of the Medieval Church of Zsámbék), In: Forschungenfragen der Steinskulptur der Arpadenzeit in Ungarn, Az István Király Múzeum Közleményei. A Pannonia Konferenciák Aktái, Fejér Megyei Múzeumok Igazgatósága, Székesfehérvár, Hungary, pp. 63-69. (in German)

Henszlmann, I. (1860) "Méthodes des proportions dans l'architecture égyptienne, Dorique et du Moyen Âge" (Proportioning methods in Egyiptian, Dorique and medieval architecture), Paris, France. (in French)

Hiscock, N. (2000) "The Wise Master Builder. Platonic Geometry in Plans of Medieval Abbeys and Cathedrals", Johns Hopkins University Press, Baltimore, MD, USA. https://doi.org/10.1353/tech.2001.0114

Hoppe, L. (1993) "A történeti építészet méretmeghatározó módszerei" (Methods of dimension design of historical architecture), ÉpítésÉpítészettudomány, 23(3-4), pp. 351-388. (in Hungarian)

Hoppe, L. (1995) "Az ötszög szerkesztése a középkorban: Hans Hammer ötszögszerkesztése" (Construction of the pentagon in the Middle Ages: Hans Hammer's pentagon construction), ÉpítésÉpítészettudomány, 25(1-2), pp. 139-171. (in Hungarian)

Hoppe, L. (1994) "Késő gótikus méretrend Hans Hammer vázlatkönyvéből" (Late Gothic unit system from Hans Hammer's sketchbook), Műemlékvédelmi Szemle, 2, pp. 5-20. (in Hungarian)

Kidson, P. (2008) "Roriczer's Iceberg", Journal of the Warburg and Courtauld Institutes, 71, pp. 1-20.

Leica Geosystems "Leica BLK360 Imaging Laser Scanner", [online] Available at: https://leica-geosystems.com/products/laser-scanners/scanners/blk360 [Accessed: 02 June 2019]

Levárdy, F. (1969) "Henszlmann alkotó egyénisége" (Henszlmann’s creative mind), Müvészettörténeti Értesítő, 18(3), pp. 193-200. (in Hungarian)

Lővei, P. (1996) "A zsámbéki rom müemléki védelmének története" (History of the monument preservation of the ruins of Zsámbék), Magyar Múemlékvédelem, 10, pp. 39-58. (in Hungarian)

Luhmann, T., Chizhova, M., Gorkovchuk, D., Hastedt, H., Chachava, N., Lekveishvili, N. (2019) "Combination of Terrestrial Laser Scanning, UAV and Close-range Photogrammetry for 3D Reconstruction of Complex Churches in Georgia", The International Archives of the Photogrammetry, Remote Sensing and Spatial Information Sciences, 42(2-W11), pp. 753-761.

https://doi.org/10.5194/isprs-archives-XLII-2-W11-753-2019

Lux, G. (1939) "A zsámbéki templomrom" (The church ruins of Zsámbék), Budapest, Hungary. (in Hungarian)

Macheridis, S. (2015) "Image-Based 3D Modeling as a Documentation Method for Zooarchaeological Remains in Waste-Related Contexts", Ethnobiology Letters, 6(2), pp. 242-248.

https://doi.org/10.14237/ebl.6.2.2015.342
Marosi, E. (1996) "A zsámbéki kolostorromok. A struktúra analízisének kísérlete" (The cloister ruins of Zsámbék. Experiment for the analysis of structure), Magyar Mủemlékvédelem, 10, pp. 59-76. (in Hungarian)

Masini, N., Fonseca, C. D., Geraldi, E., Sabino, G. (2004) "An algorithm for computing the original units of measure of medieval architecture", Journal of Cultural Heritage, 5(1), pp. 7-15.

https://doi.org/10.1016/j.culher.2002.12.001

Masini, N., Gizzi, F. T., Biscione, M., Fundone, V., Sedile, M., Sileo, M., Pecci, A., Lacovara, B., Lasaponara, R. (2018) "Medieval Archaeology Under the Canopy with LiDAR. The (Re)Discovery of a Medieval Fortified Settlement in Southern Italy", Remote Sensing, 10(10), Article number: 1598.

https://doi.org/10.3390/rs10101598

Möller, I. (1925) "A zsámbéki templom" (The church of Zsámbék), Technika, 6(5-6), pp. 69-78. (in Hungarian)

Morais, E. C., Vigh, L. G., Krähling, J. (2017) "Linear and Non-linear Seismic Analysis of a Hungarian Late Romanesque Church", Acta Technica Napocensis: Civil Engineering \& Architecture, 60(1), pp. $42-58$.

Murray, S. (1978) "The Gothic Facade Drawings in the 'Reims Palimpsest’", Gesta, 17(2), pp. 51-56. https://doi.org/10.2307/766860

Murray, S. (2002) "Reconciling the Feet at Bauvais and Amiens Cathedrals", In: Wu, N. (ed.) Ad Quadratum: The Practical Application of Geometry in Medieval Architecture, Ashgate Publishing, Farnham, UK, pp. 169-181.

Murray, S. (2014) "Plotting Gothic: A Paradox", Architectural Histories: The open access journal of the EAHN, 2(1), Article number 16. https://doi.org/10.5334/ah.bs

Ogawa, T., Hori, Y. (2019) "Comparison with Accuracy of Terrestrial Laser Scanner by Using Point Cloud Aligned with Shape Matching and best Fitting Methods", The International Archives of the Photogrammetry, Remote Sensing and Spatial Information Sciences, 42(2-W9), pp. 535-541. https://doi.org/10.5194/isprs-archives-XLII-2-W9-535-2019

Pan, Y., Dong, Y., Wang, D., Chen, A., Ye, Z. (2019) "Three-Dimensional Reconstruction of Structural Surface Model of Heritage Bridges Using UAV-Based Photogrammetric Point Clouds", Remote Sensing, 11(10), Article number: 1204. https://doi.org/10.3390/rs11101204

Quintero, M. S., Georgopoulos, A., Stylianidis, E., Lerma, J. L., Remondino, F. (2017) "CIPA's Mission", APT Bulletin: The Journal of Preservation Technology, 48(4), pp. 51-54.

Rodríguez-Gonzálvez, P., Jiménez Fernández-Palacios, B., MuñozNieto, Á. L., Arias-Sanchez, P., Gonzalez-Aguilera, D. (2017) "Mobile LiDAR System: New Possibilities for the Documentation and Dissemination of Large Cultural Heritage Sites", Remote Sensing, 9(3), Article number: 189. https://doi.org/10.3390/rs9030189

Sánchez-Aparicio, L. J., Villarino, A., García-Gago, J., GonzálezAguilera, D. (2016) "Photogrammetric, Geometrical, and Numerical Strategies to Evaluate Initial and Current Conditions in Historical Constructions: A Test Case in the Church of San Lorenzo (Zamora, Spain)", Remote Sensing, 8(1), Article number: 60. https://doi.org/10.3390/rs8010060 
Schmidt, J., Rabiger-Völlmer, J., Werther, L., Werban, U., Dietrich, P., Berg, S., Ettel, P., Linzen, S., Stele, A., Schneider, B., Zielhofer, C. (2019) "3D-Modelling of Charlemagne's Summit Canal (Southern Germany). Merging Remote Sensing and Geoarchaeological Subsurface Data", Remote Sensing, 11(9), Article number: 1111. https://doi.org/10.3390/rs11091111

Schuller, M. (2002) "Building Archeology", ICOMOS, Monuments and Sites, 7, Paris, France.

Shelby, L. R., Mark, R. (1979) "Late Gothic structural design in the 'instructions' of Lorenz Lechler", Architectura, 9(2), pp. 113-131.

Shelby, L. R. (1971) "Mediaeval Masons' templates", Journal of the Society of Architectural Historians, 30(2), pp.140-154.

Shortell, E. M. (2002) "The Plan of Saint-Quentin: Pentagon and Square in the Genesis of High Gothic Design", In: Wu, N. (ed.) Ad Quadratum: The Practical Application of Geometry in Medieval Architecture, Ashgate Publishing, Farnham, UK, pp. 123-149.

Sódor, A. (1978a) "Az építészeti tervezés alaptendenciái a középkorban" (Fundamental Tendencies of Architectural Design in the Middle Ages), University lecture notes, Budapest University of Technology, Budapest, Hungary. (in Hungarian)

Sódor, A. (1978b) "Matthes Roriczer 1496-ban megjelent fiatorony könyve" (Matthes Roriczer's pinnacle book from 1496), ÉpítésÉpítészettudomány, 10(3-4), pp. 381-421. (in Hungarian)

Sódor, A. (1981) "Hans Schmuttermayer kései középkori fiatorony könyve", (Hans Schmuttermayer's late medieval pinnacle book), Építés-Építészettudomány, 13(1-2), pp. 193-209. (in Hungarian)

Sódor, A. (1982) "Matthes Roriczer "Geometria Deutsch" és "Wimpergbüchlein" című könyveiről (1486-1490)" (About Matthes Roriczer's books of 'Geometria Deutsch' and 'Wimpergbüchlein' (1486-1490)), Építés-Építészettudomány, 14(3-4), pp. 373-405. (in Hungarian)

Somogyi, Á., Fehér, K., Lovas, T., Halmos, B., Barsi, Á. (2017) "Analysis of Gothic Architectural Details by Spatial Object Reconstruction Techniques", Periodica Polytechnica Civil Engineering, 61(3), pp. $640-651$.

https://doi.org/10.3311/PPci.10418

Sztanekné Apai, G. (1980) "Késő gótikus kápolnák Magyarországon" (Late Gothic chapels in Hungary), Doctoral Thesis, Budapest University of Technology. (in Hungarian)

Tombor, I. (1955) "Zsámbék" (Zsámbék), Képzőmüvészeti Alap Kiadóvállalata, Budapest, Hungary. (in Hungarian)

Valter, I., Tamási, J. (1987) "Zsámbék - premontrei templom és kolostorrom" (Zsámbék - Premonstratensian abbey and cloister ruins), Régészeti Füzetek, 40(1), pp. 124-125. (in Hungarian)

Valter, I. (1991a) "Zsámbék - premontrei monostorrom" (Zsámbék Premonstratensian monastery ruins), Régészeti Füzetek, 43(2), pp. 80-81. (in Hungarian)
Valter, I. (1991b) "Újabb régészeti kutatások a zsámbéki premontrei prépostsági romban 1986-1991" (The latest archaeological investigations in the ruins of the Premonstratensian Provostry of Zsámbék), Mủemlékvédelmi Szemle, 2, pp. 24-28. (in Hungarian)

Valter, I. (1992) "Zsámbék - premontrei monostorrom" (Zsámbék Premonstratensian monastery ruins), Régészeti Füzetek, 44, p. 97. (in Hungarian)

Valter, I. (1993) "Zsámbék - premontrei monostorrom" (Zsámbék Premonstratensian monastery ruins), Régészeti Füzetek, 45, p. 104. (in Hungarian)

Valter, I. (1996) "Schambek im Mittelalter" (Zsámbék in the Middle Ages), In: Jelli, M. (ed.) Schambek/Zsámbék Beiträge zur Geschichte und Volkskunde einer "schwäbischen" (donau-schwäbischen) Gemeinde im Ofner Bergland/Ungarn, Heimatverein Schambek, Gerlingen, Germany, pp. 40-69. (in German)

Warden, R. W. (2009) "Towards a New Era of Cultural-Heritage Recording and Documentation", APT Bulletin: The Journal of Preservation Technology, 40(3-4), pp. 5-10.

Watenpaugh, H. Z. (2014) "Preserving the Medieval City of Ani: Cultural Heritage between Contest and Reconciliation", Journal of the Society of Architectural Historians, 73(4), pp. 528-555.

https://doi.org/10.1525/jsah.2014.73.4.528

Wirth, J. (2015) "Villard de Honnecourt - Architecte du XIIIe siècle" (Villard de Honnecourt - Architect of the 13th century), Libraire Droz S. A., Geneva, Switzerland. (in French)

Wu, N. (2002) "The Hand of the Mind: The Ground Plan of Reims as a Case Study", In: Wu, N. (ed.) Ad Quadratum: The Practical Application of Geometry in Medieval Architecture, Ashgate Publishing, Farnham, UK, pp. 149-169.

Xu, Z., Wu, L., Shen, Y., Li, F., Wang, Q., Wang, R. (2014) "Tridimensional Reconstruction Applied to Cultural Heritage with the Use of Camera-Equipped UAV and Terrestrial Laser Scanner", Remote Sensing, 6(11), pp. 10413-10434.

https://doi.org/10.3390/rs61110413

Zádor, A. (1966) "Henszlmann Imre építészetelmélete és a gótizálás kialakulása" (Imre Henszlmann's theory of architecture and the emergence of design in Gothic style), Építés- és Közlekedéstudományi Közlemények, 10(2), pp. 207-228. (in Hungarian)

Zenner, M. T. (2002) "A Proposal for Constructing the Plan and Elevation of a Romanesque Church Using Three Measures", In: Wu, N. (ed.) Ad Quadratum: The Practical Application of Geometry in Medieval Architecture, Ashgate Publishing, Farnham, UK, pp. 25-57.

Zsoldos, A. (ed.) (2001) "Pest Megye monográfiája I/2. A honfoglalástól 1686-ig", (Monography of Pest County I/2. From the Hungarian conquest of the Carpathian Basin to 1686), Pest Megye Monográfia Közalapítvány, Budapest, Hungary. (in Hungarian) 